\title{
Severe Accident Test Station Design Document
}

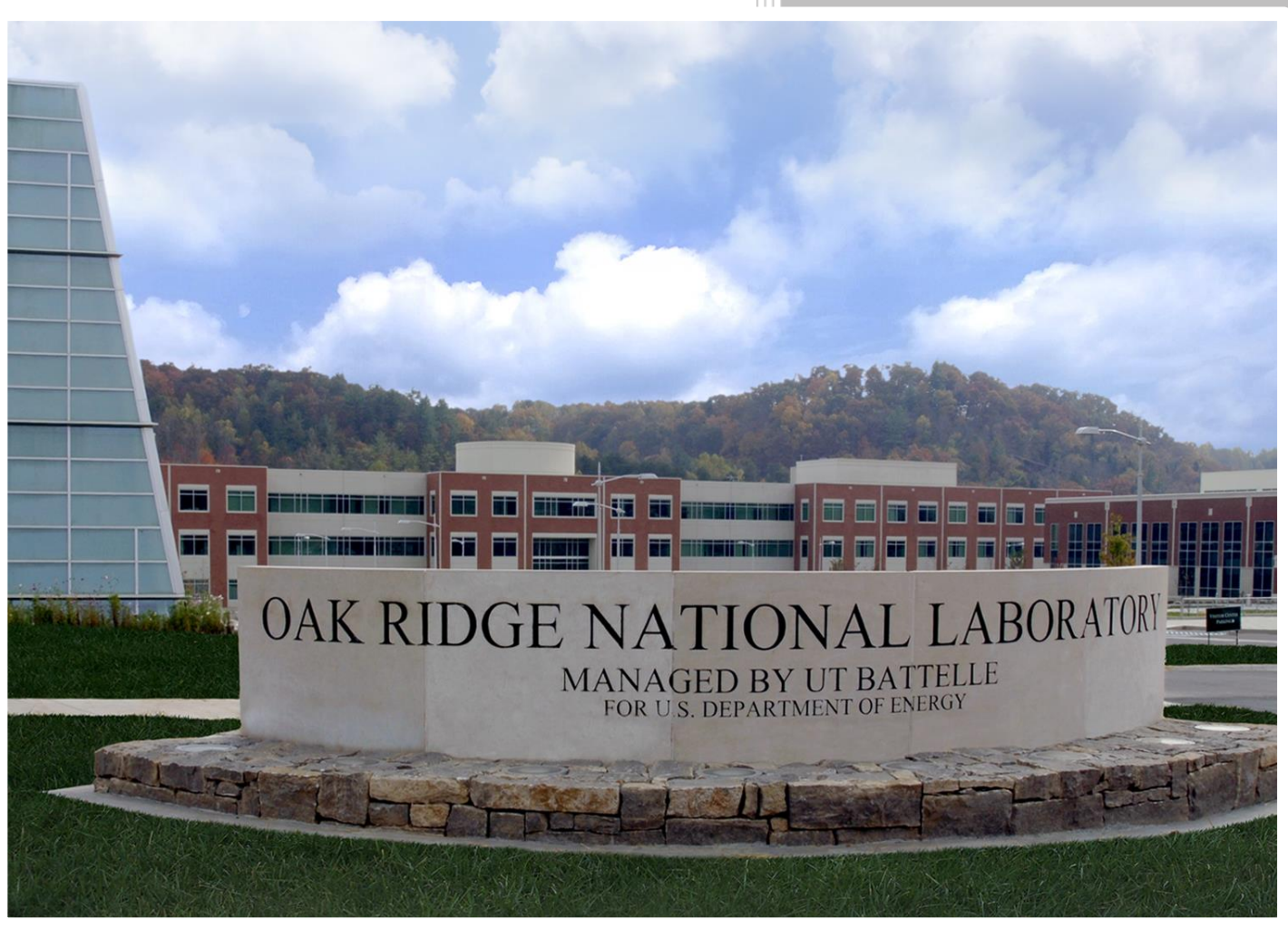

Approved for public release. Distribution is unlimited.
M. Snead

Y. Yan

M. Howell

J. Keiser

K. Terrani

Date: September 2015 


\section{DOCUMENT AVAILABILITY}

Reports produced after January 1, 1996, are generally available free via US Department of Energy (DOE) SciTech Connect.

Website http://www.osti.gov/scitech/

Reports produced before January 1, 1996, may be purchased by members of the public from the following source:

National Technical Information Service

5285 Port Royal Road

Springfield, VA 22161

Telephone 703-605-6000 (1-800-553-6847)

TDD 703-487-4639

Fax 703-605-6900

E-mail info@ntis.gov

Website http://www.ntis.gov/help/ordermethods.aspx

Reports are available to DOE employees, DOE contractors, Energy Technology Data Exchange representatives, and International Nuclear Information System representatives from the following source:

Office of Scientific and Technical Information

PO Box 62

Oak Ridge, TN 37831

Telephone 865-576-8401

Fax 865-576-5728

E-mail reports@osti.gov

Website http://www.osti.gov/contact.html

This report was prepared as an account of work sponsored by an agency of the United States Government. Neither the United States Government nor any agency thereof, nor any of their employees, makes any warranty, express or implied, or assumes any legal liability or responsibility for the accuracy, completeness, or usefulness of any information, apparatus, product, or process disclosed, or represents that its use would not infringe privately owned rights. Reference herein to any specific commercial product, process, or service by trade name, trademark, manufacturer, or otherwise, does not necessarily constitute or imply its endorsement, recommendation, or favoring by the United States Government or any agency thereof. The views and opinions of authors expressed herein do not necessarily state or reflect those of the United States Government or any agency thereof. 
DOE Fuel Cycle Research and Development Program - Advanced LWR Fuels

\title{
Severe Accident Test Station Design Report
}

\author{
M. Snead \\ Y. Yan \\ M. Howell \\ J. Keiser \\ K. Terrani
}

Date Published: September 2015

\author{
Prepared by \\ OAK RIDGE NATIONAL LABORATORY \\ Oak Ridge, Tennessee 37831-6283 \\ managed by \\ UT-BATTELLE, LLC \\ for the \\ US DEPARTMENT OF ENERGY \\ under contract DE-AC05-00OR22725
}





\section{CONTENTS}

Page

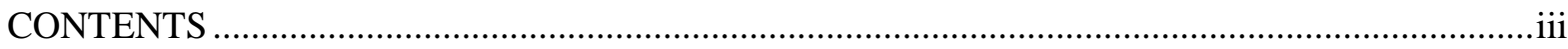

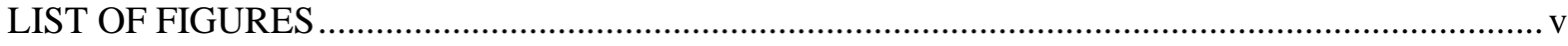

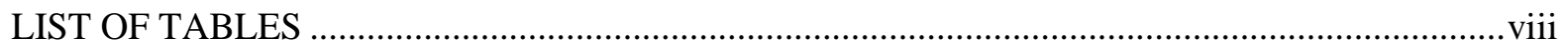

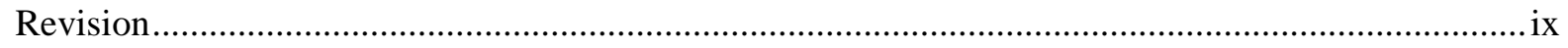

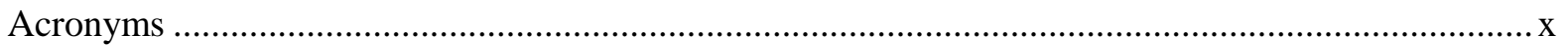

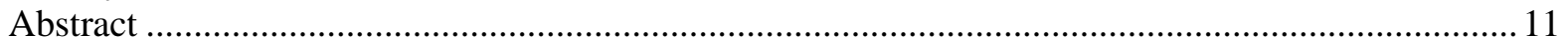

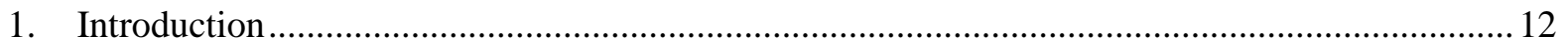

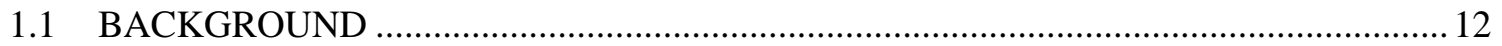

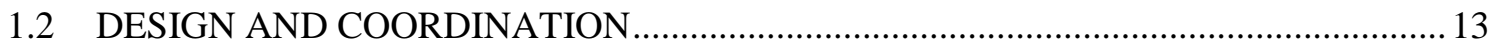

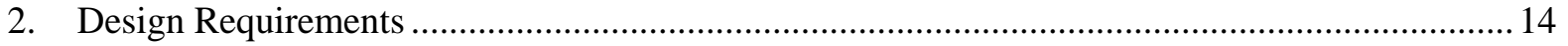

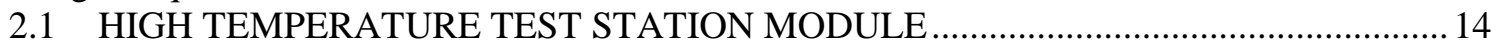

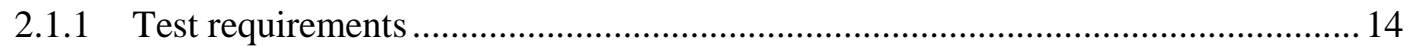

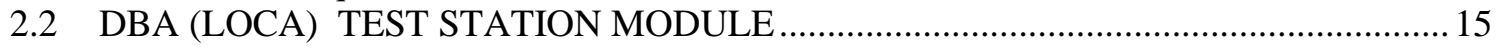

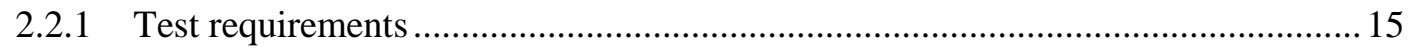

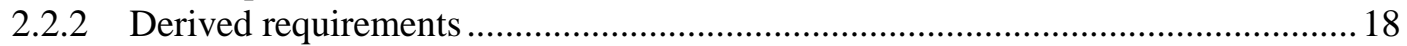

2.3 DBA AND BDBA TEST STATION MODULES DESIGN REQUIREMENTS .............19

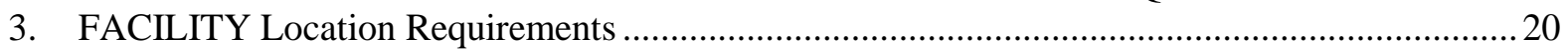

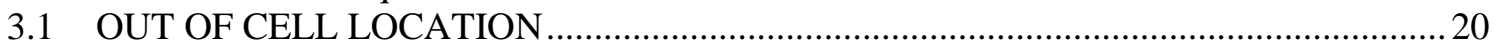

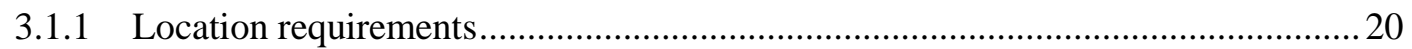

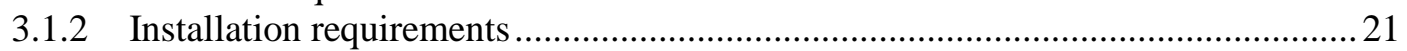

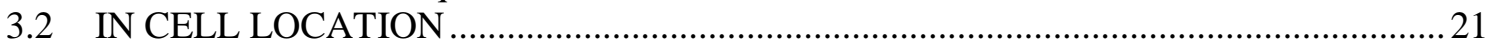

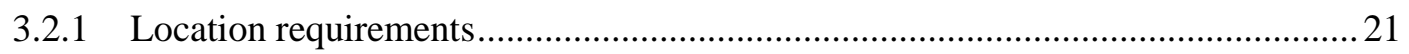

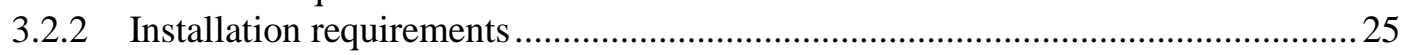

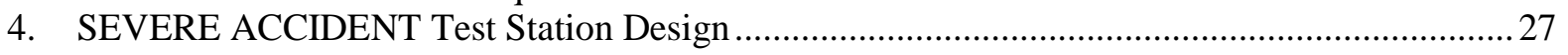

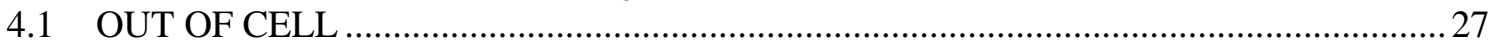

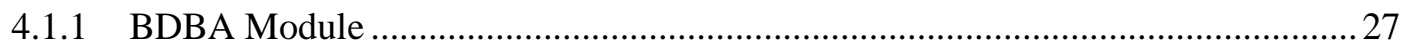

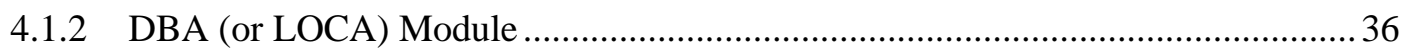

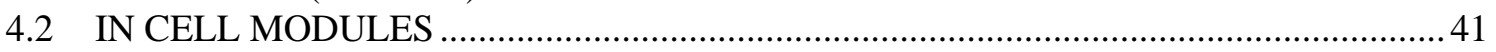

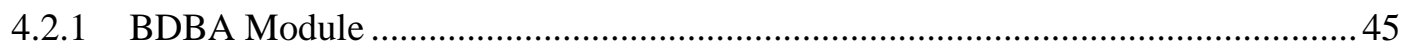

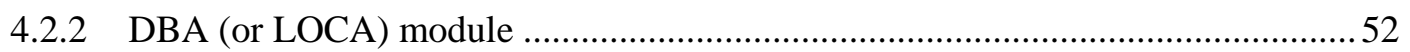

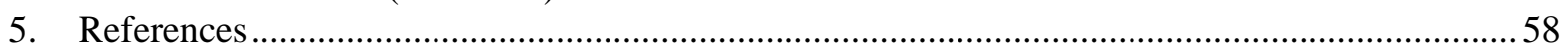

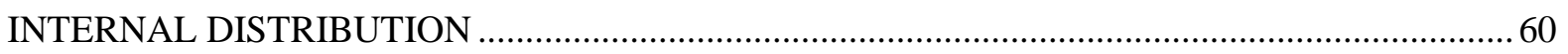

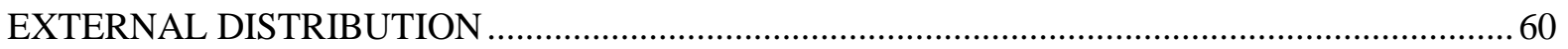





\section{LIST OF FIGURES}

\section{Figure}

Figure 1 Schematic of the thermal history used for LOCA integral tests with 300-mm-long samples. Zirconia-filled, as-fabricated cladding samples are tested out-of-cell, and

\section{fueled high-burnup cladding samples are tested in-cell.}

Figure 2 A typical temperature history desired for the steam oxidation test with short defueled samples $(\approx 25$

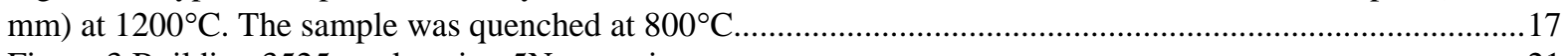

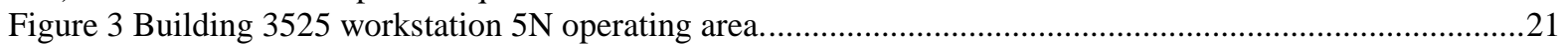

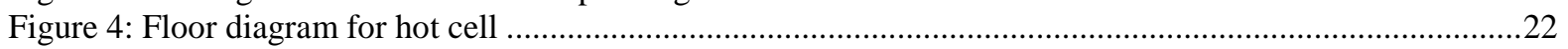

Figure $5 \mathrm{An}$ example of a typical service plug just prior to installation ...........................................................23

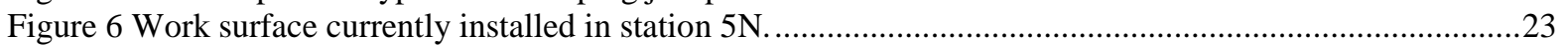

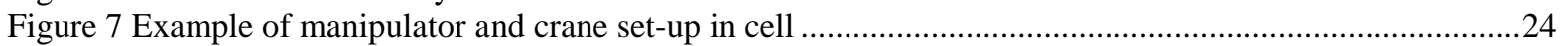

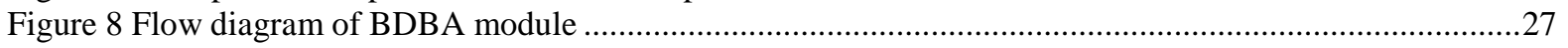

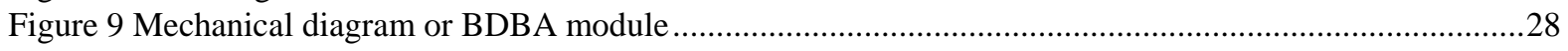

Figure 10 Steam generator and low temperature steam delivery lines ............................................................30

Figure 11 Gas line fittings at bottom of furnace with ball valve ....................................................................

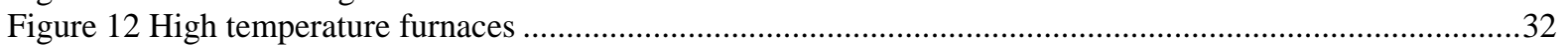

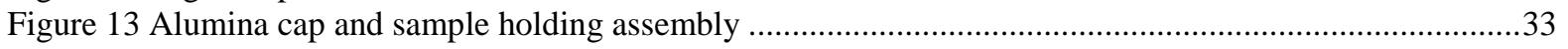

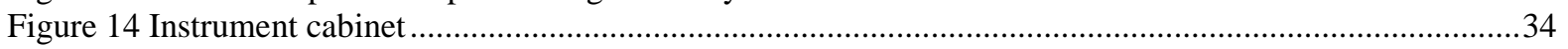

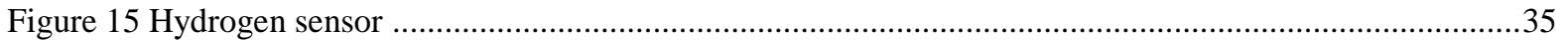

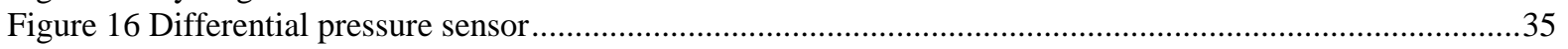

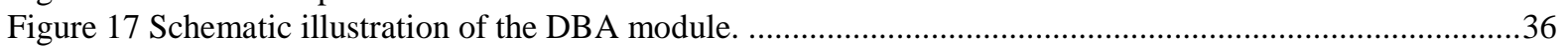

Figure 18 Overview of ORNL's out-of-cell LOCA integral test apparatus..........................................................37

Figure 19 LOCA integral test train assembly and quartz tube .........................................................................

Figure 20 Temperature and pressure histories during ramp for typical out-of cell LOCA Integral Test with 9x9

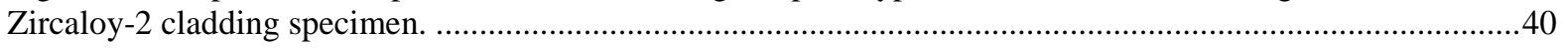

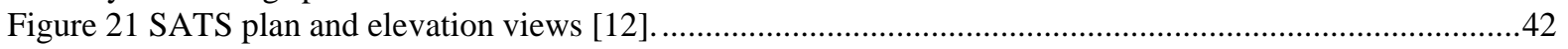

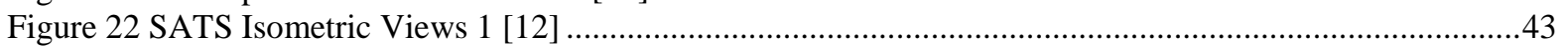

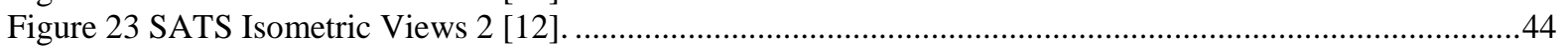

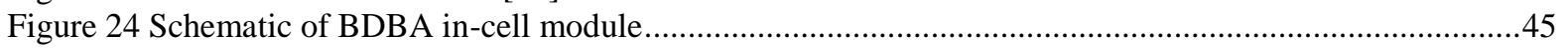

Figure 25 BDBA in-cell module located at hot cell facility .......................................................................46

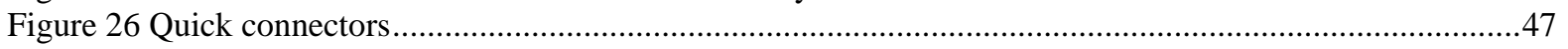

Figure 27 Power connections for the high temperature furnaces on the out-of-cell module (left) and in-cell

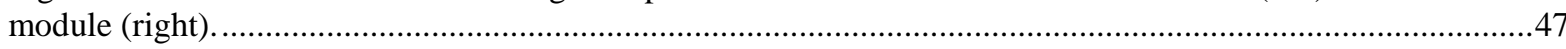

Figure 28 Furnace bracket arrangements on the out-of-cell (left) and in-cell (right) attachments for the high temperature furnaces ...............................................................................................................................48

Figure 29 Connector panel on the in-cell module which facilitates connections for thermocouples, pressure

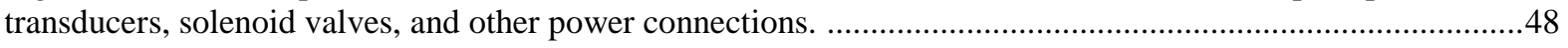

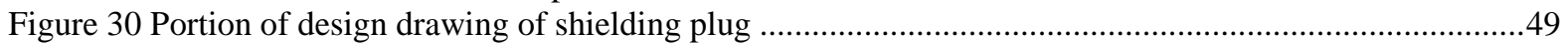

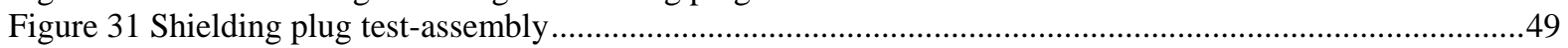

Figure $32 \mathrm{CVD}-\mathrm{SiC} 1700^{\circ} \mathrm{C} 4 \mathrm{~h}$ specimen mass change comparison between out-of-cell and in-cell modules.50 Figure 33 APMT $1450^{\circ} \mathrm{C} 4 \mathrm{~h}$ specimen mass change comparison between out-of-cell and in-cell modules .......51

Figure 34 Furnace bases of the out-of-cell (left) and in-cell (right) attachments for the LOCA furnaces............53

Figure 35 Furnace brackets of the out-of-cell (left) and in-cell (right) attachments for the LOCA furnaces.......53

Figure 36 Quench tank valves of the out-of-cell (left) and in-cell (right) attachments for the LOCA furnaces...54

Figure 37 Thermocouple panel of the in-cell LOCA system..........................................................................54

Figure 38 Temperature profile of the control thermocouple for a LOCA test performed with the out-of cell LOCA module. The simple was controlled heated to $1200^{\circ} \mathrm{C}$ at $5^{\circ} \mathrm{C} / \mathrm{s}$, held at $1200^{\circ} \mathrm{C}$ for $60 \mathrm{~s}$, cooled to $800^{\circ} \mathrm{C}$

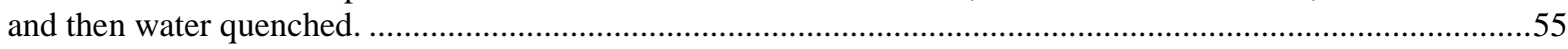

Figure 39 Temperature profile of the control thermocouple for LOCA test performed with the in- cell LOCA module. The simple was controlled heated to $1200^{\circ} \mathrm{C}$ at $5^{\circ} \mathrm{C} / \mathrm{s}$, held at $1200^{\circ} \mathrm{C}$ for $180 \mathrm{~s}$, cooled to $400^{\circ} \mathrm{C}$ and then water quenched. 



\section{LIST OF TABLES}

Table

Page

Table 1 Configuration and design parameters for the BDBA modules (in- and out-of-cell).............................14

Table 2 Configuration and design parameters for the DBA modules (in- and out-of-cell). ............................17

Table 3 Water delivery rates for test tube diameters ...................................................................29

Table 4 Water volume requirements if system operates with $100 \%$ steam at the maximum design flow rate.....29 


\section{REVISION}

\begin{tabular}{ccl}
\hline Revision & Date & \\
\hline 1 & $09 / 22 / 2012$ & Committed as DOE milestone M3FT-12OR0208061 and internal review \\
2 & $06 / 13 / 2013$ & Updated with review comments and LOCA out of cell installation information \\
3 & $11 / 11 / 2013$ & Submitted as DOE milestone M2FT-13OR0202242 \\
4 & $11 / 22 / 2013$ & Updated with In-cell BDBA module section and submit internal review \\
5 & $8 / 18 / 2015$ & Update with finternal review comments \\
\hline
\end{tabular}




\section{ACRONYMS}

\begin{tabular}{cl||cl}
\hline Acronym & \multicolumn{1}{c||}{ Description } & Acronym & \multicolumn{1}{c}{ Description } \\
\hline ANL & Argonne National Laboratory & ORNL & Oak Ridge National Laboratory \\
AOO & Anticipated operational occurrences & RIA & Reactivity insertion accident \\
BDBA & Beyond design basis accident & SATS & Severe accident test station \\
DBA & Design based accident & SAR & Safety analysis report \\
DOE & Department of Energy & USQD & Un-reviewed safety question \\
fetermination
\end{tabular}




\begin{abstract}
The purpose of the ORNL severe accident test station (SATS) is to provide a platform for evaluation of advanced fuels under projected beyond design basis accident (BDBA) conditions. The SATS delivers the capability to map the behavior of advanced fuels concepts under accident scenarios across various temperature and pressure profiles, steam and steam-hydrogen gas mixtures, and thermal shock. The overall facility will include parallel capabilities for examination of fuels and irradiated materials (in-cell) and non-irradiated materials (out-of-cell) at BDBA conditions as well as design basis accident (DBA) or loss of coolant accident (LOCA) conditions. Also, a supporting analytical infrastructure to provide the data-needs for the fuel-modeling components of the Fuel Cycle Research and Development (FCRD) program will be put in place in a parallel manner.

This design report contains the information for the first, second and third phase of design and construction of the SATS. The first phase consisted of the design and construction of an out-of-cell BDBA module intended for examination of non-irradiated materials. The second phase of this work was to construct the BDBA in-cell module to test irradiated fuels and materials as well as the module for DBA (i.e. LOCA) testing out-of-cell, The third phase was to build the in-cell DBA module. The details of the design constraints and requirements for the in-cell facility have been closely captured during the deployment of the out-of-cell SATS modules to ensure effective future implementation of the in-cell modules.
\end{abstract}




\section{INTRODUCTION}

\subsection{BACKGROUND}

During light water nuclear reactor operation three categories of accidents are recognized that are as follows:

i) Anticipated operational occurrences (AOO),

ii) postulated or design basis accidents (DBA), and

iii) beyond design basis accidents (BDBA).

The first category covers minor occurrences (e.g. turbine trip) that occur during normal operation $\left(\sim 10^{-2}\right.$ events / reactor year) and are generally mitigated by active safety systems and operator intervention. Examples of a DBA are a reactivity insertion accident (RIA) or a loss of coolant accident (LOCA). DBAs, as the name should suggest, provide the basis for design of the reactor and its components so that the system response is enveloped within a manageable window during these occurrences. The probability of DBAs are deemed to be anywhere between $10^{-2}-10^{-5}$ events / reactor year. BDBA are deemed largely improbable $\left(<10^{-5}\right.$ events / reactor year) and therefore do not impose any constraint on reactor design requirements. However, the experience with nuclear reactor operation over the past five decades differs from the description above since no DBA events have been recorded while multiple BDBA events have taken place (e.g. Three Mile Island and Fukushima Daiichi).

The focus of this manuscript is on the severe accident test station (SATS) design that aims to provide a platform for examination of advanced fuel and cladding materials under conditions pertaining to DBA and BDBA scenarios. This capability is deemed necessary to inform effective and optimized research and development in the area of advanced nuclear fuel and materials for light water reactors (LWRs).

The motivation behind development and deployment of advanced nuclear fuel and materials in LWRs is multifaceted. Advanced LWR fuel concepts meant for replacing the current urania-zirconium alloy fuel system are intended to enable larger operational margins (higher burnup and power, and meet or exceed current cycle lengths), prove economical in their mature state, enable beneficial impacts on the fuel cycle, and finally, and of significant importance, provide enhanced margins of safety during accidents. The latter is the area of focus for the SATS to examine the response of these advanced fuel concepts under DBA and BDBA conditions.

Two workshops were organized in support of the design and development of a SATS. The first workshop, titled "Severe Accident Test Station Definition Workshop", was organized in San Diego, CA in January 2012. The second workshop titled "International Meeting on Examination of Current and Advanced Nuclear Fuels under Simulated Accident Conditions" was organized in Berkeley, CA during May 2012. The workshops provided an opportunity to gather national and international experts to discuss design parameters and ensure optimized deployment of the SATS. The outcome of these workshops is captured in the following section of this document.

The SATS modules were initially deployed out-of-cell to examine non-irradiated materials. The same modules were then replicated for in-cell (ORNL's 3525 Fuel Hot-Cell) operation to then examine irradiated fuels and materials. Throughout the design of the SATS, the operational constraints within the hot-cell (e.g. spatial and constrains with using manipulators to operate the unit, limit on the volume and type of gases released from the system, etc.) have been thoroughly captured to enable an efficient transition from the out-of cell module to the in-cell capability. The document includes the first stage of the deployment of the SATS-the construction of the out-of-cell BDBA module, as well as the second phase where the in-cell BDBA and out-of-cell DBA modules were constructed. The first stage was completed as scheduled in FY-12. The out-of-cell DBA module was completed in mid FY-13 as scheduled and the deployment of the in-cell BDBA module was completed at the end of FY-13. The in- 
cell DBA module was deployed in FY15 to complete phase three. Nether the BDBA or DBA modules will actually be placed in the hot cell until the first experiments are scheduled. This is to prevent degradation of the system while it is not being used. Residual radiation in the hot cell could shorten the life of some SATS components thus it appears prudent to delay insertion. The BDBA and DBA modules were relocated and tested outside the hot cell facility. They are ready to be inserted in the cell as soon as the first test is scheduled and are currently available for hot cell staff to train on its operation prior to insertion.

\subsection{DESIGN AND COORDINATION}

As mentioned earlier, the SATS design consists of two modules focused on assessing the performance of materials under DBA and BDBA conditions, respectively. The DBA evaluation is conducted using the LOCA Integral Test system. This system was originally developed at Argonne National Laboratory (ANL) and played an essential role in formulating the most recent set of regulatory test criteria from the U.S. Nuclear Regulatory Commission with respect to DBA loss of coolant accidents [1].

After decommissioning of the ANL unit, the domestic capability to perform this type of experiment was lost. Although BDBA scenarios had been simulated on various occasions over the past decades on the urania-zirconium alloy system [2],[3], no standard system existed for simulation of BDBA scenarios and an original design was needed. The design approach for the SATS is to replicate and optimize the already demonstrated LOCA integral test system and steam testing system to simulate BDBA conditions at much higher temperatures than the LOCA integral test system.

The conditions (e.g. temperature, pressure, gas flow rate, etc.) in the core during BDBAs can have a wide range of values. Thus, it was recognized that a complimentary set of capabilities was needed to provide comprehensive understanding of the phenomenon that govern the evolution of advanced fuel and cladding materials under these scenarios. The complimentary capabilities already in place at ORNL are as follows:

- High-pressure Steam Testing: Testing capability up to 34 bar in pure steam or steam-hydrogen mixtures.

- Thermogravimtery Experiments: to extract more detailed kinetics and investigate transient phenomenon. Microbalance testing in 1 bar steam is now available at up to $1500^{\circ} \mathrm{C}$ with a magnetic system to decouple the exposure environment from the weighing mechanism.

- Materials Coupling Experiments: To examine detrimental interaction of dissimilar metals (e.g. Zr-alloys and stainless steel) adjacent to one another under accident scenarios.

- Hydriding Apparatus: to capture any deviation in behavior of hydrogen charged metals (particularly Zr alloys) from the hydrogen-free state under BDBA and LOCA scenarios.

- Post Quench Ductility Testing: to investigate the mechanical behavior of cladding materials after simulation of accident scenarios.

These complimentary capabilities enable separate effect experiments to determine the state-dependent physical, chemical and thermo-mechanical behavior of advanced fuel cladding materials. Coupled with the integral testing capabilities in the SATS, overarching analysis of experimental results to gain fundamental knowledge of the behavior of current and advanced fuel cladding systems under accident scenarios is possible. 


\section{DESIGN REQUIREMENTS}

\subsection{HIGH TEMPERATURE TEST STATION MODULE}

\subsubsection{Test requirements}

The objective of the high temperature test station module is to provide a facility where samples of candidate fuel cladding materials can be exposed to conditions that are more severe than those used for the generally recognized LOCA test conditions. More specifically, the system needs to be capable of exposing samples to rapidly flowing steam or a steam/hydrogen mixture at temperatures of at least $1600^{\circ} \mathrm{C}$. Ultimately the system must be suitable for testing short sections of a radioactive fuel rod; therefore this system must be built in a hot cell operated by remote control and manipulators.

Table 1 provides a summary of the design parameters for the BDBA modules of the SATS. Note that the gas pressures during the tests are limited to atmospheric condition. This was deemed appropriate during the discussions held in the BDBA workshops. The pressure effect (important for certain materials such as $\mathrm{SiC}$ and chromia forming steels) was to be captured during the separate effects tests and coupled with the integral test results from the BDBA module of the SATS.

Table 1 Configuration and design parameters for the BDBA modules (in- and out-of-cell).

\begin{tabular}{lll}
\hline \multicolumn{1}{c}{ Requirements } & \multicolumn{1}{c}{ BDBA Module } & \multicolumn{1}{c}{ Comments } \\
\hline $\begin{array}{l}\text { Sample configuration } \\
\text { Sample length }\end{array}$ & Rod $10-12 \mathrm{~mm}$ OD or coupons & \\
Hot zone length & $>25 \mathrm{~mm}$ uniform temp & \\
Minimum temperature & $1500^{\circ} \mathrm{C},>1600^{\circ} \mathrm{C}$ desired & \\
$\begin{array}{l}\text { Steam flow rate } \\
\text { Heating rate }\end{array}$ & $3.0-7.0 \mathrm{mg} /\left(\mathrm{cm}^{2} . \mathrm{s}\right)$ & \\
Cooling rate & Faster is desirable & Depending on test tube material \\
Quenching conditions & Faster is desirable & capability \\
& Thermal shock test desirable & needed \\
Test time & Limited by operator work & Hydrogen poses a safety risk in \\
& schedule & \\
Test chamber environment & Steam, steam-hydrogen or argon \\
Test chamber pressure & Atmospheric pressure & \\
Sample internal pressure & Atmospheric pressure & \\
Schedule out-of-cell & Build in FY2012 & \\
Schedule in-cell & Build in FY2013 & \\
Temperature measurement & Thermocouple near sample & \\
\hline
\end{tabular}




\subsection{DBA (LOCA) TEST STATION MODULE}

\subsubsection{Test requirements}

Test parameters and requirements for DBA (LOCA) were well discussed and the relevant test procedures were established at ANL according to the NRC requirements. The LOCA test apparatus, pre-test sample characterization, post-test nondestructive examination results, and post-test destructive examination results are described in detail by Yan et al. [4] to [7].

The DBA module should be able to perform two functions:

- LOCA integral tests using long $(\approx 300 \mathrm{~mm})$ fueled cladding samples tested up to $1200^{\circ} \mathrm{C}$ and at high internal pressure $(\sim 8 \mathrm{MPa})$

- Oxidation-quench tests using short $(25 \mathrm{~mm})$ defueled cladding samples tested at $1200^{\circ} \mathrm{C}$ and water quenched at $800^{\circ} \mathrm{C}$

These tests are described in detail below.

Table 2 summaries the main requirements for this DBA (LOCA) unit.

An out-of-cell unit was built for thermal-benchmarking purposes and for generating data for nonirradiated materials. This test unit shares the same steam generator, and control and data acquisition systems as the BDBA system. The LOCA integral and oxidation-quench tests units are distinguished by their different test trains holding the samples in position within the DBA furnace.

\subsubsection{LOCA Integral test unit}

One of NRC's central regulations used in nuclear plant licensing deals with postulated loss-of-coolant accidents (10 CFR 50.46). The LOCA integral tests were designed to investigate the performance of high burnup irradiated fuel, which has undergone ballooning, and rupture under LOCA conditions. The LOCA-Integral test train was designed to externally heat a $300 \mathrm{~mm}$ long fuel rod segment up to $1200^{\circ} \mathrm{C}$ by an infra-red (IR) radiation furnace under initial high internal pressure ( $\sim 8 \mathrm{MPa}$ inside the tube). The internal pressure is generated by high-pressure argon gas, and the pressure is monitored using top and bottom pressure transducers.

Temperature control and monitoring are extremely important in conducting LOCA integral and oxidation quench tests, because the time-at-temperature for the transition between ductile and brittle behavior is a strong function of temperature. The furnace power and sample temperature are controlled by feedback from the designated type-S (Pt/Pt-Rh) thermocouple output through a proportional-integraldifferential (PID) controller to the furnace power. Sample heat-up occurs quickly for short samples but temperature overshoot can be avoided by an integrated and well-instrumented control system.

A quartz tube provides an enclosed volume for steam flow and the water quench of the $300 \mathrm{~mm}$ rod segment, both the steam and water are introduced through the bottom of the unit. The test train is centered within the quartz tube by means of two perforated spacer disks. Swagelok fittings are used above the specimen to connect to the high-pressure gas line and top pressure gauge and below the specimen to connect to the bottom pressure-gauge line. The test train for the LOCA-integral tests is supported at the top to minimize specimen bowing. (Figure 19 gives more detail of the test train).

Figure 1 shows a schematic of the temperature history of the LOCA integral tests used for both outof-cell and in-cell testing. Because of the high thermal mass of the sample and the thermocouples welded 
(non-irradiated) or strapped (irradiated) directly on the LOCA sample, temperature control is easier than for the short, defueled cladding oxidation-quench samples (see the temperature history in Figure 1). For e.g. the reference control parameters for current BWR cladding are: 8.28-MPa (1200 psig) internal pressure with $\mathrm{Ar}$ at $\mathrm{RT}$ and $300^{\circ} \mathrm{C}, 5^{\circ} \mathrm{C} / \mathrm{s}$ heating rate, $1200^{\circ} \mathrm{C}$ hold temperature, variable hold time, $3^{\circ} \mathrm{C} / \mathrm{s}$ cooling rate from the hold temperature to $800^{\circ} \mathrm{C}$, and rapid cooling from bottom-flooding water quench at $800^{\circ} \mathrm{C}$.

As these parameters are controlled by software (LabView), they can be adjusted from test to test. Online data of interest include the time response of the bottom pressure transducer at RT and $300^{\circ} \mathrm{C}$, burst temperature, and burst pressure.

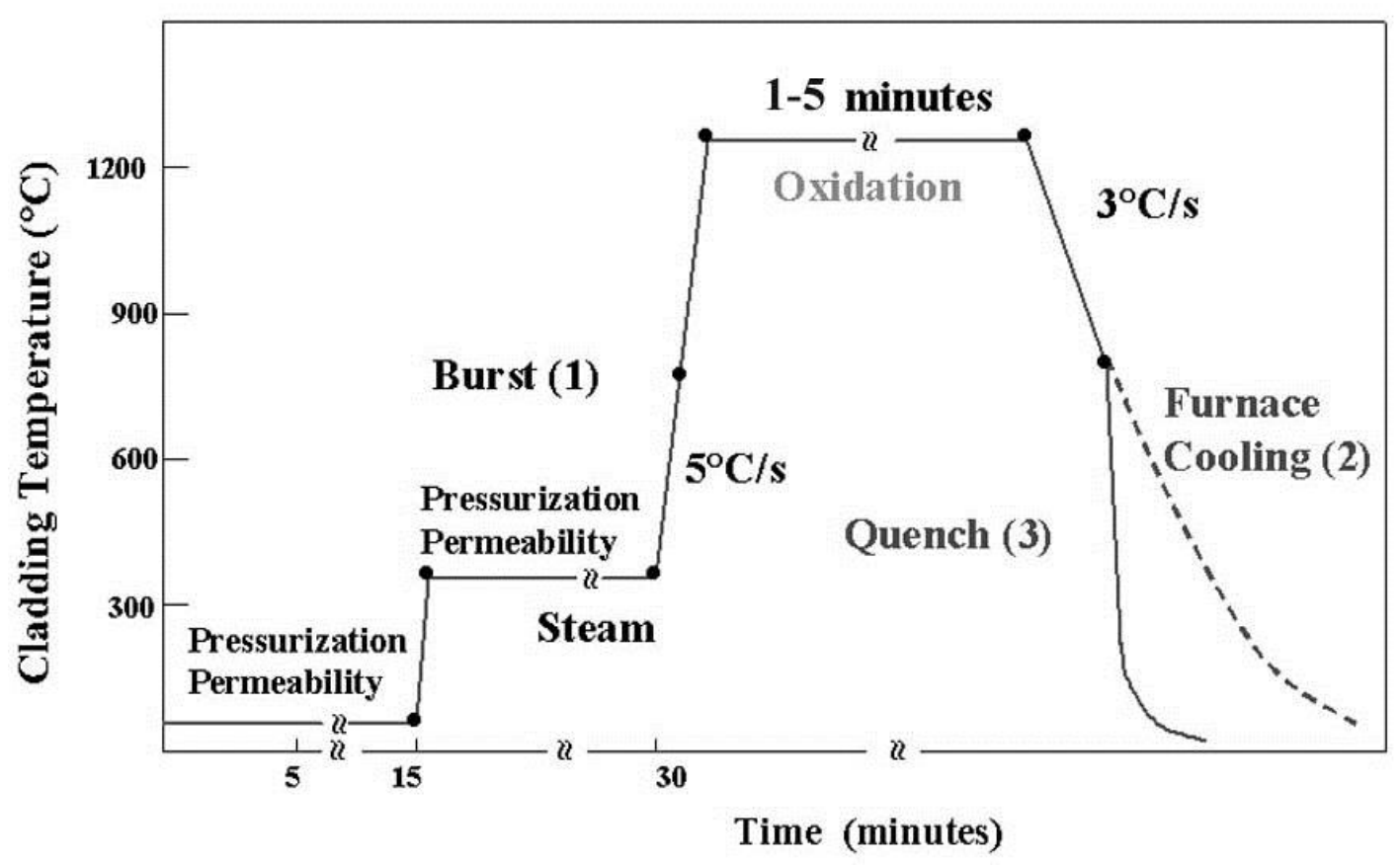

Figure 1 Schematic of the thermal history used for LOCA integral tests with $300 \mathrm{~mm}$ long samples. Zirconia-filled, as-fabricated cladding samples are tested out-of-cell, and fueled high-burnup cladding samples are tested in-cell.

\subsubsection{Oxidation-quench test unit}

Oxidation tests conducted on defueled high-burnup cladding samples are needed to characterize the evolution with time at temperature of the oxygen pickup and of the oxide thickness and morphology. The oxidized high-burnup samples are also used to determine post-test ductility as a function of corrosion layer thickness, hydrogen content and high-temperature oxidation level. These data are used as a guideline to determine the test parameters of the LOCA integral tests.

Oxidation-quench tests do not require the high-pressure connection or pressure transducers. Steam, at near-atmospheric pressure, flows up through the quartz-tube test chamber at $0.32 \pm 0.05$ $\mathrm{g} / \mathrm{cm}^{2} / \mathrm{min}$ (5.3 g/min for a $48 \mathrm{~mm}$ internal diameter quartz tube) and exits the chamber into a condenser or exhaust. Following oxidation and slow-cooling phases, steam flow is turned off, and quench water is 
introduced through the bottom of the quartz tube, filling the tube to provide very rapid sample cooling to $70-100^{\circ} \mathrm{C}$ at the desired time and temperature during cooling.

Figure 2 shows a typical temperature profile for the $1200^{\circ} \mathrm{C}$ oxidation test. This sample temperature profile meets the requirements as specified by the NRC in the ANL-proposed procedure of recommended temperature ramp rate of $\geq 20^{\circ} \mathrm{C} / \mathrm{s}$ to within $200^{\circ} \mathrm{C}$ of the target temperature and $\geq 2{ }^{\circ} \mathrm{C} / \mathrm{s}$ thereafter [4]. Cooling rate is known to significantly affect the post quench ductility of the oxidized samples [10]. Exact details on how the post-quench ductility is affected by the cooling rate are not fully understood and therefore it is recommended the average cooling rate to the $800^{\circ} \mathrm{C}$ quench temperature is $\approx 12 \pm 2{ }^{\circ} \mathrm{C} / \mathrm{s}$.

Table 2 summaries the main requirements for this DBA (LOCA) unit.

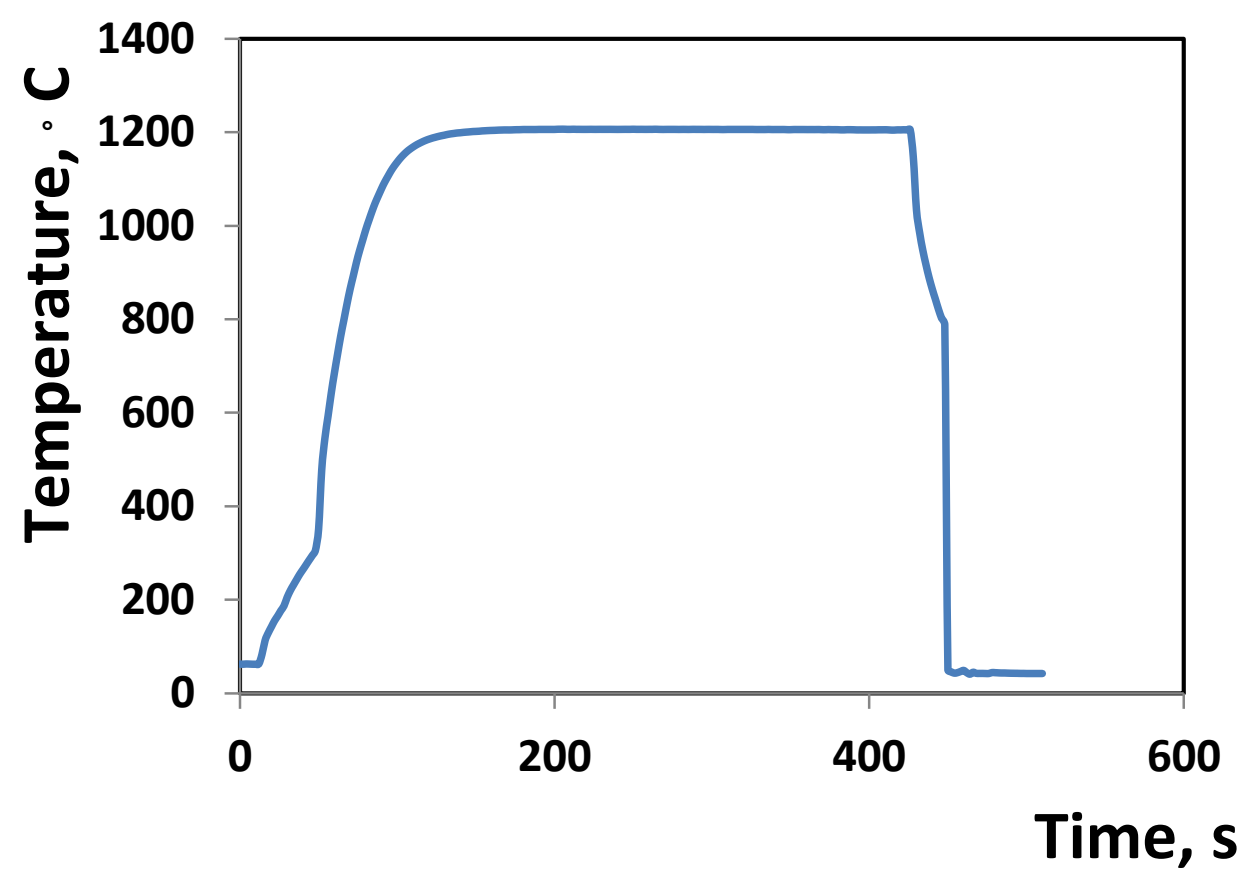

Figure 2 A typical temperature history desired for the steam oxidation test with short defueled samples $(\approx 25$ $\mathrm{mm})$ at $1200^{\circ} \mathrm{C}$. The sample was quenched at $800^{\circ} \mathrm{C}$.

Table 2 Configuration and design parameters for the DBA modules (in- and out-of-cell).

\begin{tabular}{lll}
\hline \multicolumn{1}{c}{ Requirements } & LOCA integral unit & \multicolumn{1}{c}{ Oxidation quench unit } \\
\hline Sample configuration & Fueled Rod OD 9-12 mm & Defueled cladding OD 9-12 mm \\
Sample length & 300mm (12") long with $250 \mathrm{~mm}$ & $50 \mathrm{~mm}\left(2^{\prime \prime}\right)$ long \\
Hot zone length & $\left(10^{\prime \prime}\right)$ of fuel & \\
Minimum temperature & $100 \mathrm{~mm}(4 ")$ uniform temperature & $100 \mathrm{~mm}\left(4^{\prime \prime}\right)$ uniform temperature \\
& $\geq 1200^{\circ} \mathrm{C}$ & $\geq 1200^{\circ} \mathrm{C}$ \\
& & $220^{\circ} \mathrm{C} / \mathrm{s}$ to within $200^{\circ} \mathrm{C}$ of the \\
Heating rate & $5^{\circ} \mathrm{C} / \mathrm{s}$ & $\begin{array}{l}\text { target temperature and } \geq 2{ }^{\circ} \mathrm{C} / \mathrm{s} \\
\text { thereafter }\end{array}$ \\
& & $\approx 12 \pm 2^{\circ} \mathrm{C} / \mathrm{s}$ \\
Cooling rate & $3^{\circ} \mathrm{C} / \mathrm{s}\left(2-15^{\circ} \mathrm{C} / \mathrm{s}\right)$ & Water quench from $800^{\circ} \mathrm{C}$ \\
\hline
\end{tabular}




\begin{tabular}{|c|c|c|}
\hline Requirements & LOCA integral unit & Oxidation quench unit \\
\hline Quenching conditions & Raise water around sample & Raise water around sample \\
\hline Steam flow rate & $10-15 \mathrm{mg} /\left(\mathrm{cm}^{2} \cdot \mathrm{s}\right)$ & $0.32 \pm 0.05 \mathrm{~g} / \mathrm{cm}^{2} / \mathrm{min}$ \\
\hline Test time & $\geq 30 \min @ 1200^{\circ} \mathrm{C}$ & $\geq 30 \min @ 1200^{\circ} \mathrm{C}$ \\
\hline Test chamber environment & Steam, steam-hydrogen or argon & Steam, steam-hydrogen or argon \\
\hline Test chamber pressure & Atmospheric pressure & Atmospheric pressure \\
\hline Sample internal pressure & $\geq 8.96 \mathrm{MPa}(1300 \mathrm{psig})$ & $\geq 8.96 \mathrm{MPa}(1300 \mathrm{psig})$ \\
\hline Schedule out-of-cell & \multicolumn{2}{|c|}{ Built in FY 2013} \\
\hline Schedule in-cell & \multicolumn{2}{|c|}{ Built in FY 2014 and 2015} \\
\hline Temperature measurement & Temperature control on sample & $\begin{array}{l}\text { Temperature control on sample } \\
\text { holder (welded to sample) }\end{array}$ \\
\hline Quench water flow rate & Water rise rate $\geq 15 \mathrm{~mm} / \mathrm{s}$ & Water rise rate $\geq 15 \mathrm{~mm} / \mathrm{s}$ \\
\hline
\end{tabular}

\subsubsection{Derived requirements}

These requirements are derived from previous operating experience and design requirements stated in section 2.1.1.

LOCA integral test

1. The inside of the test chamber (i.e. quarts tube) shall be large enough to accommodate bending of the $300-\mathrm{mm}$ long specimen at a small angle $\left(<5^{\circ}\right)$ from the centerline without severe impact on test chamber wall.

2. There shall be at least four high temperature thermocouples (operation temperature $\geq 1200^{\circ} \mathrm{C}$ ) to control and monitor the specimen temperature, two of which shall be within the test chamber.

3. There shall be an additional two or three thermocouples to monitor the steam temperature.

4. The specimen shall be attached to a test train through a pressure-tight seal that allows up to $5^{\circ}$ of lateral movement from the furnace centerline.

5. The specimen shall be able to be pressurized using external gas (argon). The gas supply should be remotely controlled (by a solenoid valve) attached to the furnace base frame.

6. The top of the test chamber and test train shall be constrained from lateral movement due to the thermal shock process.

7. The test chamber will be atmospheric pressure, but shall be sealable to accommodate water quench pressure surge at $800^{\circ} \mathrm{C}$.

8. The system shall be able to provide a high flow rate of relatively low temperature steam $\left(<200^{\circ} \mathrm{C}\right)$ for cooling the specimen rapidly to simulate the thermal shock under severe accident conditions. The estimated steam flow rate is approximately $10-15 \mathrm{mg} /\left(\mathrm{cm}^{2} \cdot \mathrm{s}\right)$.

9. The outlet of the test chamber shall be connected to a condenser or exhaust for safely handling entrained hot steam and mixed gas.

10. Temperature shall be controlled within $5^{\circ} \mathrm{C}$ of the set temperature and checked at least every second.

11. The quartz tube shall have external shielding to contain the tube in case of rupture during the quench.

Oxidation Quench test

1. The test chamber should be atmospheric pressure, but sealable to accommodate water quench pressure surge at $800^{\circ} \mathrm{C}$.

2. The test chamber shall be of sufficient length above and below the heated zone and be fixed to the furnace base to sustain the water quench (pressure design) and associated lateral movement.

3. There shall be at least four high temperature thermocouples (operation temperature $\geq 1200^{\circ} \mathrm{C}$ ) to control and monitor the specimen temperature, two of which shall be within the test chamber. 
4. There shall be an additional two or three thermocouples to monitor the steam temperature.

5. There shall be an in-cell water tank to quench the heated specimen. The tank shall have a capacity sufficient to cover the entire specimen length in the test chamber during flooding.

6. The quench water inlet shall be remotely controlled (with a solenoid valve).

7. A water reservoir shall be available so that the water in the test chamber can be drained at the end of a test.

8. The outlet of test chamber shall be connected to a condenser or exhaust for safely handling entrained hot steam and mixed gas.

9. Temperature shall be controlled within $5^{\circ} \mathrm{C}$ of the set temperature and checked at least every second.

10. The quartz tube shall have external shielding to contain the tube in case of rupture during the quench.

\subsection{DBA AND BDBA TEST STATION MODULES DESIGN REQUIREMENTS}

The steam supply system and furnace base can be shared between the BDBA and DBA modules as well as the control system.

Steam generator:

- The system shall be capable of providing a continuous flow of steam.

- The system shall have the capability to monitor (or calculate) the steam flow rate.

- Steam flow into the test chamber shall be remotely controlled.

Base:

- The furnace base shall have passage accommodations for thermocouples and steam inlet lines.

- The base should be designed to catch fuel and cladding debris that can be removed/cleaned (using manipulators.) 


\section{FACILITY LOCATION REQUIREMENTS}

This section contains the limitation that the facilities place on the test station modules as well as what is required from the facilities to operate the test station.

\subsection{OUT OF CELL LOCATION}

\subsubsection{Location requirements}

\subsubsection{Space and Facilities}

Space limitations

1. Table with base frame requires $122 \times 122 \mathrm{~cm}(4 \times 4 \mathrm{ft})$ of floor space

2. Instrument cabinet space

3. Room temperature: $20 \pm 5^{\circ} \mathrm{C}$

4. Room humidity: $\sim 60 \%$

Ventilation requirements:

1. Exhaust required for test stand and gas cabinet

Furnace Power requirements

1. BDBA furnaces (both) require $240 \mathrm{~V}, 21 \mathrm{Amps}, 8 \mathrm{KVA}$ Step Down transformer

2. DBA furnace $480 \mathrm{~V} / 30 \mathrm{~A}, 50 / 60 \mathrm{~Hz}, 8.0 \mathrm{kVA}$

3. Steam generator Power- 1220 Watts/5.3 Amps @ 230 VAC, $60 \mathrm{~Hz}$

4. Other electric components $110 \mathrm{~V}, 20 \mathrm{Amps}$

Air supply requirements:

1. Compressed air ( $\geq 30 \mathrm{psig}$ ) required for pneumatic valves and water pump

Cooling water requirements:

1. Cooling water supply and drain must be sized to provide flow of at least $5.6 \mathrm{l} / \mathrm{min}$ (1.5 gallon/min) of water

2. Cooling water temperature of $25 \pm 5^{\circ} \mathrm{C}$

Other requirements:

1. Cabinet for compressed gases

2. Cabinet rated for flammable gas (hydrogen)

\subsubsection{Health and Safety}

A research and safety summary (RSS 10788.0) was written for the laboratory space (building 4500S, room B151) at ORNL. This contains the hazards of the experimental work and the safety requirements to enable a safe operating area. This process is part of the ORNL Integrated Safety Management System, where after work is defined, hazards are analyzed to develop controls before work is performed.

The following requirements are of importance for the specific DBA and BDBA modules:

- The system shall have a pressure relief valve for the inert gas high-pressure line used in the DBA system.

- If the test chamber for the DBA module is made of quartz, the parts beyond the ends of the furnace shall be shrouded to prevent dispersal in case there is a violent rupture.

- The outlet of the test chamber shall be connected to an exhaust or a condenser for safely handling entrained hot steam and mixed gas.

- Hydrogen monitoring and safety control system (representatives of the ORNL Fire Department and Industrial Hygiene have determined that $\mathrm{H}_{2}$ can be vented into the laboratory exhaust system provided the air flow into the exhaust is at least 100 times the volume of $\mathrm{H}_{2}$ gas being released) 


\subsubsection{Installation requirements}

- The furnaces for both the LOCA and the BDBA tests shall be mounted on a stable base frame, and allow for the option to exchange/replace components.

- A horizontally adjustable base plate should be installed to allow the specimen to be aligned properly at the center of the furnace

- The furnace base should allow for space for the quench tank, high pressure valve and line, and furnace cooling water condenser to be mounted on it for the DBA module

- The thermocouple leads for the DBA module shall be mounted so that it can be easily removed when the test train is removed.

- For the DBA module control $3 \mathrm{~S}$-type thermal couples for furnace control, $1 \mathrm{~K} / \mathrm{S}$ type thermo couple for the steam system is required.

- LOCA furnace cooling water flow rate of $>2 \mathrm{~L} / \mathrm{min}$

- LOCA furnace cooling water pressure of $\geq 30 \mathrm{psi}$

- LOCA high pressure Ar gas supply $\geq 3000$ psi

\subsection{IN CELL LOCATION}

\subsubsection{Location requirements}

\subsubsection{Space and Facilities}

\section{Building}

The high-temperature test facilities, both the DBA and BDBA modules will be located in the ORNL Building 3525 North Hot Cell at the corner work station designated as 5N and shown in Figure 3.

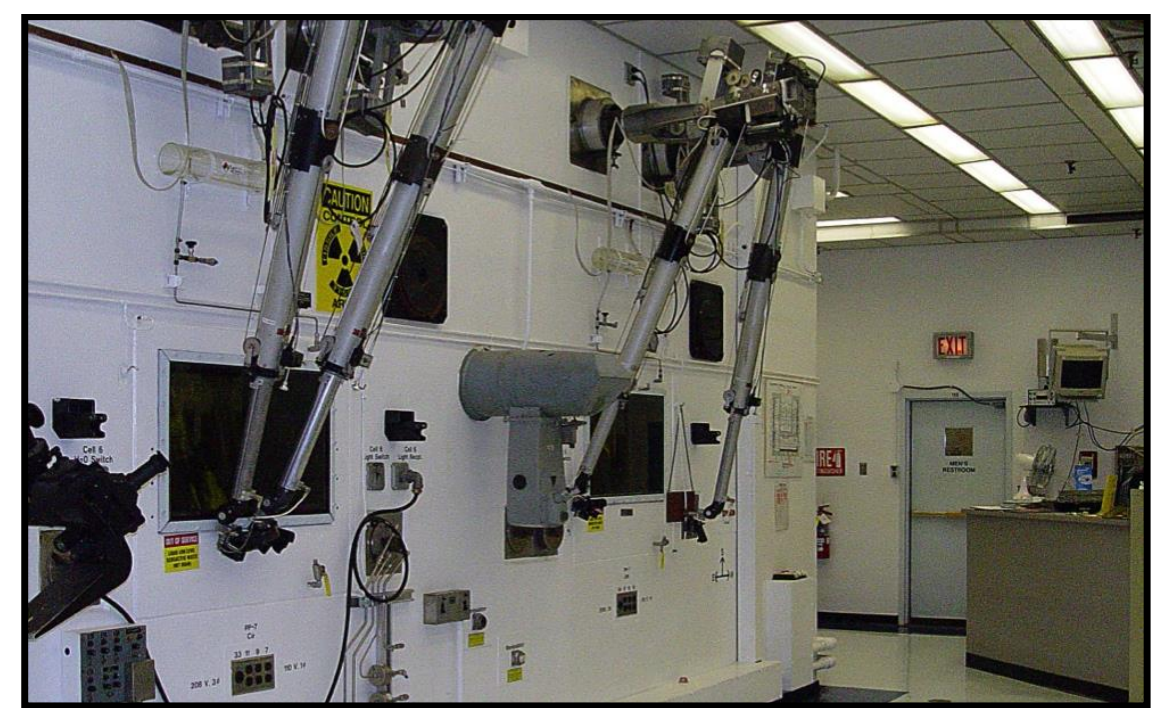

Figure 3 ORNL Building 3525 workstation 5N operating area.

The corner work station $5 \mathrm{~N}$ in the North Hot Cell has the advantage of 2 work station windows oriented $90^{\circ}$ apart, one on the north face and the other on the west face of the hot cell. Figure 4 gives a floor diagram of the $5 \mathrm{~N}$ station and the interfacing sites.

The hot cell entrance limit is $\mathrm{H}$ x W x D $=72$ " x 48 " x 48 ". It is desirable that the furnace base be 
somewhat smaller perhaps limited to 42" x 42 " with a height limit of 66 ".

Through-wall service plugs containing wiring and gas lines will be utilized to connect the in-cell and out-of-cell equipment and provide any necessary utilities not already present in the hot cell. Figure 5 gives an example of a typical service plug just prior to installation. The stainless steel part with the $\mathrm{O}-$ rings goes in first and makes the airtight seal near the inside surface of the hot cell wall. The lead plug with the spiral groves is larger in diameter and provides the necessary shielding at the outside surface of the hot cell wall. The connecting bar through the center keeps everything in the proper position. The hot cell wall is 3 feet thick and made of high density concrete. The lead piece provides equivalent shielding to the wall.

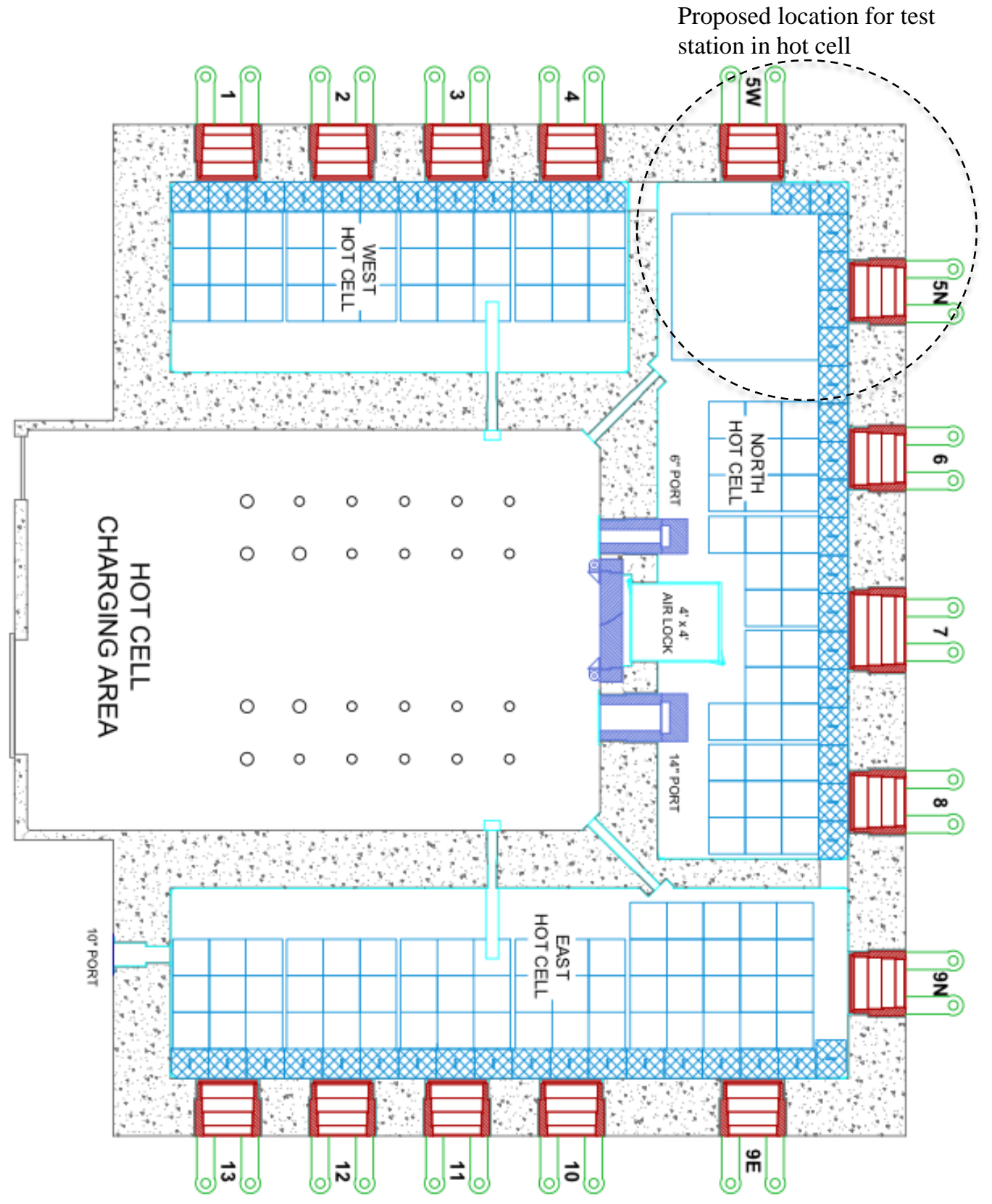

Figure 4: Floor diagram for hot cell 


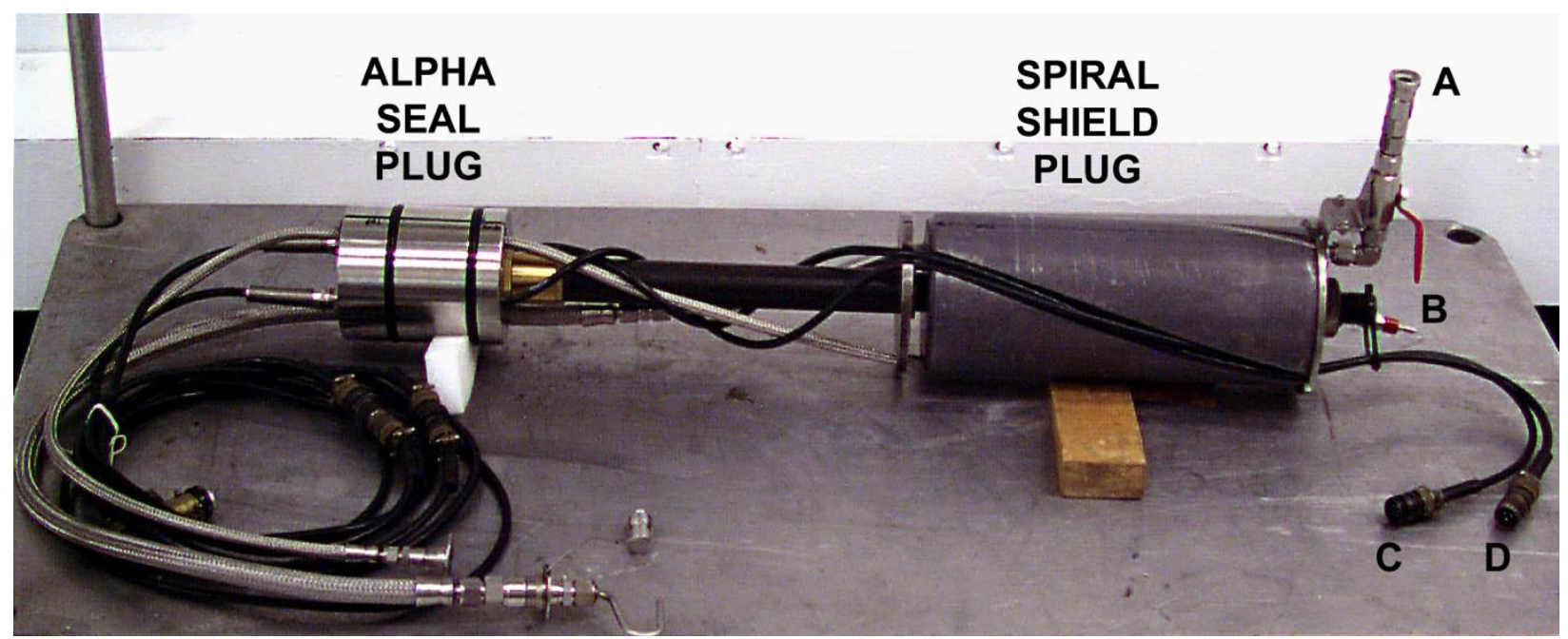

Figure 5 An example of a typical service plug just prior to installation

The hot cell also has a special work surface, which is installed approximately 14 inches lower than the normal work surfaces in the hot cells. This surface allows greater flexibility in the design of the high-temperature test facilities and provides a pre-drilled level surface for mounting the support structure. Figure 6 shows the work surface prior to its installation in the hot cell. It is approximately $2.4 \mathrm{~m}(8 \mathrm{ft})$ wide and $1.8 \mathrm{~m}(6 \mathrm{ft})$ deep and is made of $25 \mathrm{~mm}(1$ ") thick aluminum.

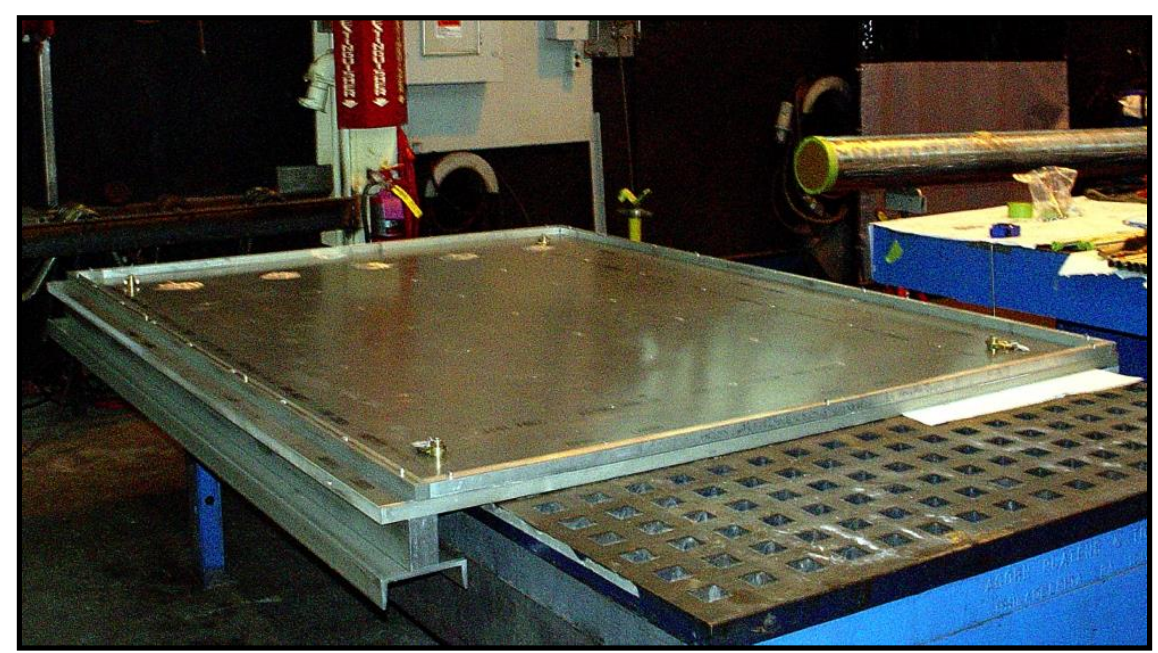

Figure 6 Work surface currently installed in station $5 \mathrm{~N}$.

Other equipment such as the furnace power supplies, sweep gas supplies, flow meters, process control displays, and control computers will be located outside the main hot cells in the operating area at the face of the hot cell or in the Charging Area (see Figure 4) located behind the hot cell. There is ample space available in both of these areas. 


\section{Operability with manipulators}

The operational height for manipulators is approximately 6" to 48" above the platform. This is highly dependent on the content of the cell. Figure 7 gives an example of the manipulators and the crane available in the cell.

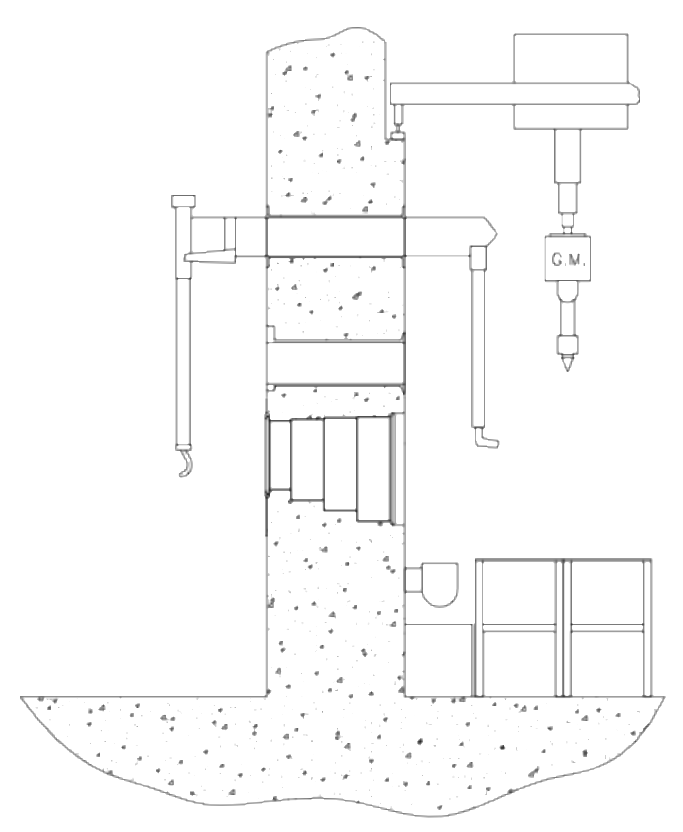

\section{Figure 7 Example of manipulator and crane set-up in cell}

The following is required for easier manipulator function. The out of cell design has been reviewed and discussed with hot cell operators to ensure the in-cell system was optimized for manipulator operations.

- The base plate connection, the specimen attachment, the thermocouple plug, the solenoid valves for steam, water, and gas pressure control, shall be accessible and maintainable at $\geq 6$ " height with manipulators.

- Electrical and piping connections to the station system shall be remotely detachable by manipulators.

- The electronic cables to the connections on the furnace must be labeled, and be easily identifiable through the hot cell window.

- High pressure line (up to 3000 psig with inert gas Ar) to the $300 \mathrm{~mm}$-long fuel sample shall be remotely detachable by manipulators.

- The test equipment should be mounted on a stable base plate fixed to the work surface

\section{Additional service limits and requirements}

- Due to irradiated and fuel materials that will be tested no electronic controlled equipment can be used in the hot cell (close to test tubes) as these will deteriorate due to the radiation and cause failure of the equipment.

- The high operating cost of the hot cells should be considered in designing for equipment maintenance and replacement. 
- The current water limit in the ORNL hot cell is 10 liters. It is desirable to have an out-of cell water reservoir linked to the in-cell steam system.

- For DBA (LOCA) furnace, the specimen shall be able to be pressurized from a gas (Ar) external to the hot cell. The gas supply should be controlled by a solenoid valve attached to the furnace base frame. A small HEPA filter on gas line is required to trap the fine radioactive particles. The HEPA filter will be installed on Ar gas line between the hot cell outlet and Ar gas tank. .

\subsubsection{Health and Safety}

The health and safety requirements for the hot cell were captured in the hot cell safety analysis report (SAR), which is captured in the following reports: ORNL/3525/SAR R5, and ORNL/3525/TSR R8.

To ensure that the SATS will fall into the safety requirements of the SAR an Un-reviewed Safety Question Determination (USQD) was filled out to evaluate the new activity and determine if it causes changes to the SAR that would require DOE approval. A typical activity may result in physical changes and new operational procedures and both types of impacts were evaluated. The characteristics of the test such as new energy sources, magnitude of all of the energy sources, hazardous materials involved, similarity to other testing activities, the need to have radioactive material pass through the hot cell wall into the operating area, etc. will determine if changes need to be made to the SAR.

For high pressure operation the following should be taken into account:

- The DBA (LOCA) module will have high-pressure samples and quench of high temperature samples that can cause the test chamber to rupture; therefore the test chamber shall have sufficient volume to accommodate pressure surges.

- The system shall have a pressure relief valve for the inert gas high-pressure line that will be used to pressurize the LOCA integral sample.

- If the LOCA test chamber is made of quartz, the parts beyond the ends of the furnace shall be shrouded to prevent dispersal in case there is a violent rupture.

For steam and water in the hot cell the following should be considered:

- The hot cell has a 10-liter water limit for evaporation in the cell.

- Two options exist for handling steam, it can be condensed or vented through an exhaust to the HEPA filter system.

- Quench water will need to be collected and evaporated in cell.

The infrared furnace for the in-cell DBA module requires cooling water and the cooling water should be supplied in a closed loop system to prevent contamination.

The use of hydrogen is of concern in the closed hot cell space. Hydrogen levels should be limited to $1 \%$. This can be achieved by mixing the hydrogen with air when venting it out of the cell. A safety system will need to be installed to ensure hydrogen levels stay below the required limit. The use of hydrogen will be included in the USQD study.

\subsubsection{Installation requirements}

Equipment should be installed to optimize operability with manipulators. Refer to section 3.2.1.1. The following suggestions are made to assist with installation:

- It is necessary to construct the station with lifting eyes or chains so that it may be moved within the hot cell for transfer. 
- The entire system shall be modularized so that its major components may be transferred into the hot cell individually.

Other installation requirements will be the same as that for the out-of-cell system (3.1.2). Additional requirements are the installation of service plugs between the operating area and the cell for lines such as cooling water, gas supply, cabling, etc. 


\section{SEVERE ACCIDENT TEST STATION DESIGN}

\subsection{OUT OF CELL}

\subsubsection{BDBA Module}

The BDBA module consists of four components:
1. Steam delivery system
2. Test furnace(s)
3. Control system
4. Safety system

Figure 8 show the flow diagram of the module indicating the BDBA part of the system in dotted lines to indicate the interfaces between the two systems. Figure 9 gives more detail on the valve requirements.

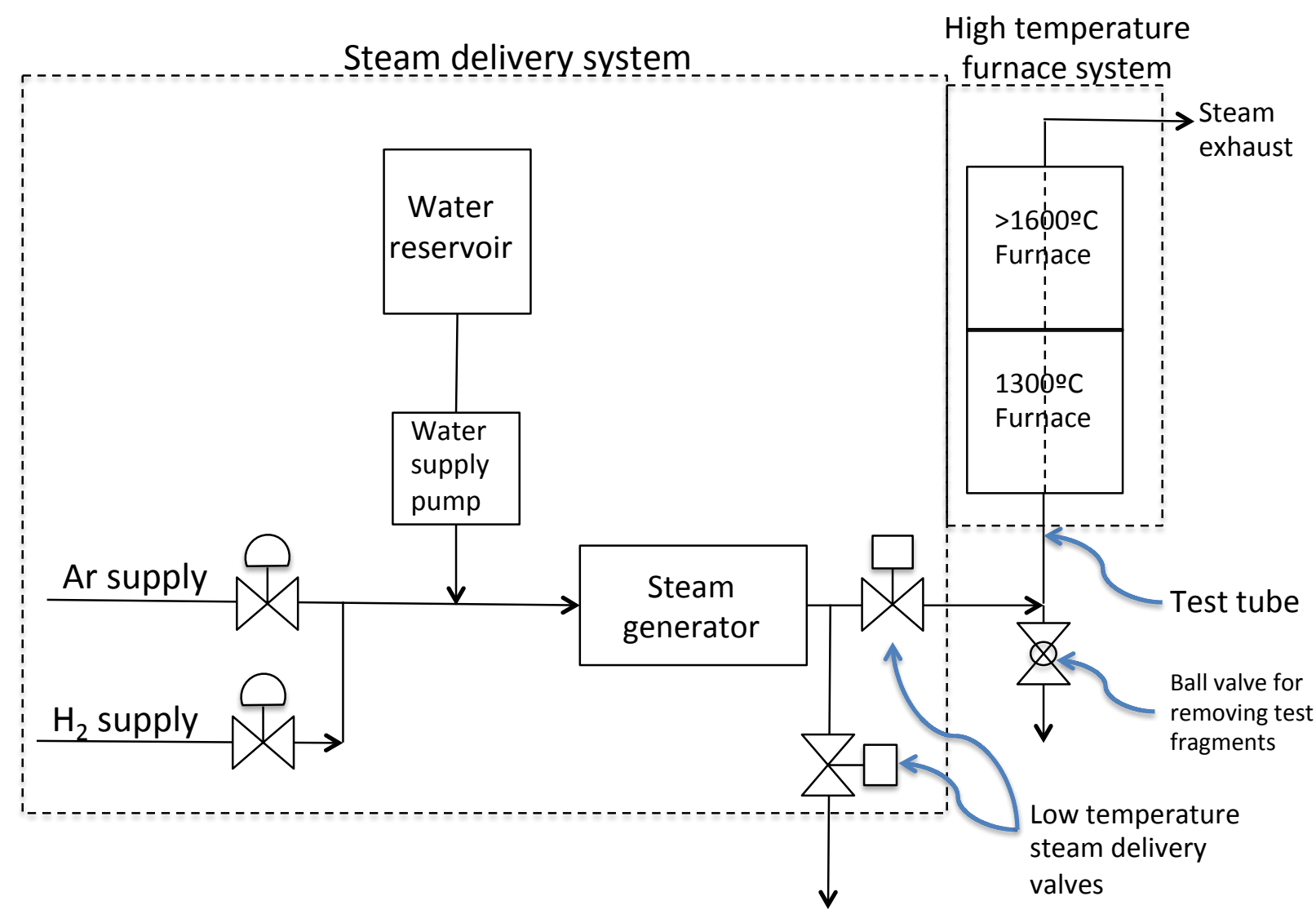

To DBA (LOCA) system

Figure 8 Flow diagram of BDBA module 


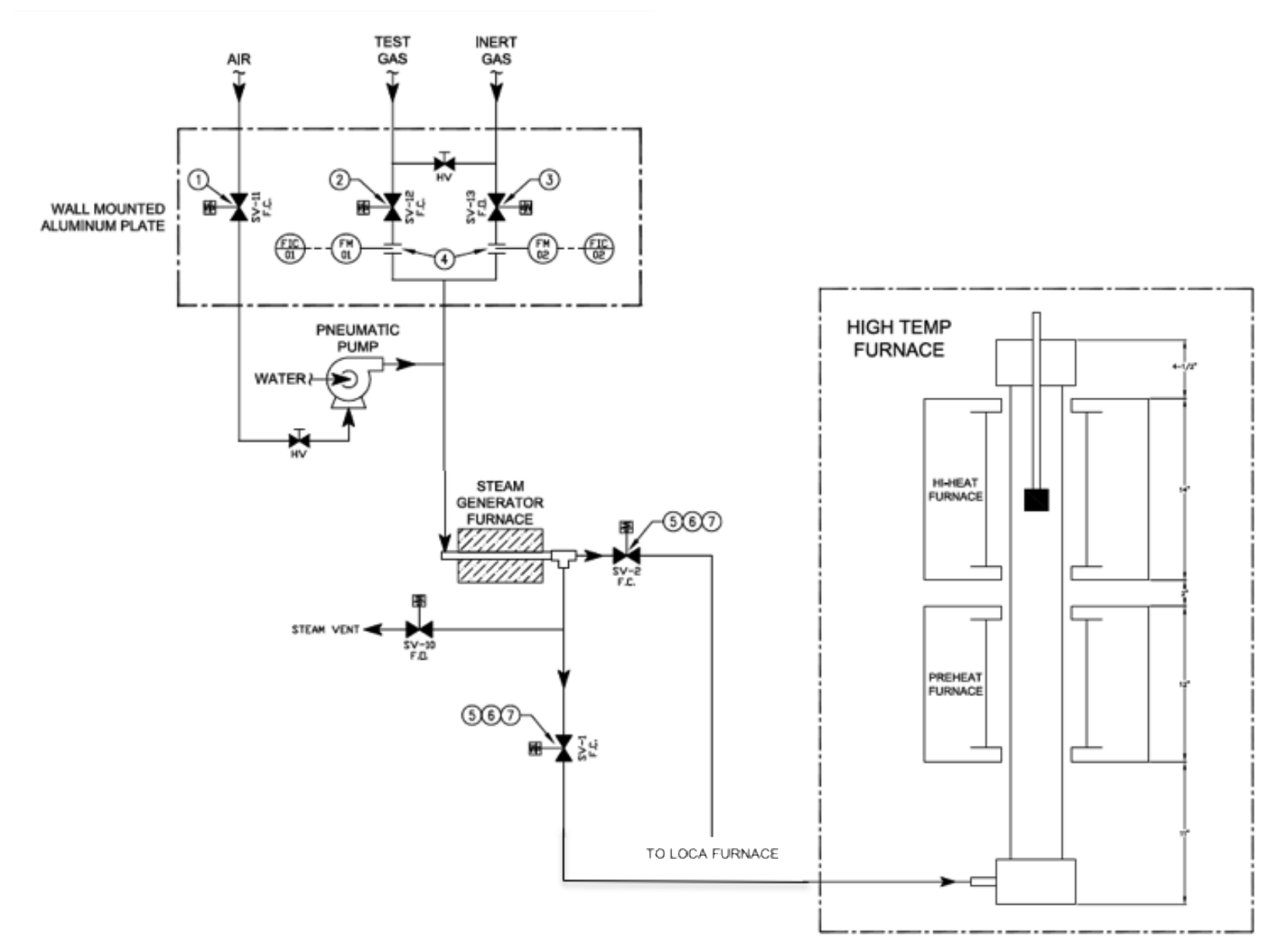

Figure 9 Mechanical diagram or BDBA module

\subsubsection{Steam Delivery System}

The steam delivery system is comprised of the following major components:

1. Water reservoir

2. Water supply pump

3. Steam generator

4. Low temperature steam delivery valves

5. Test tube (water delivery line)

6. Hydrogen supply

\section{Water supply pump}

The design requirements mentioned in Sections 2.1 and 2.3 as well as that of the DBA module in Section 2.2 (water supply pump will be shared by the two modules) determined the size of the water supply pump.

The BDBA design calls for the system to be capable of delivering steam at a rate of $3.0-7.0 \mathrm{mg} \cdot \mathrm{cm}^{-2} \cdot \mathrm{s}^{-1}$, therefore the cross sectional area of the test tube was one of the critical parameters in determining the pump size and the required heat input. In order to accommodate a corrosion sample of $12.7 \times 19.0 \times 1.59$ $\mathrm{mm}$ or a fuel rod with $11 \mathrm{~mm} \mathrm{OD}$, the test tube needed to have an inside diameter of at least $19 \mathrm{~mm}$. 
Consequently, the minimum size for a furnace tube was $\sim 25 \mathrm{~mm}$ OD and $19 \mathrm{~mm}$ ID. A larger diameter tube would provide more space between the sample and the tube wall, but a larger tube would also require a higher rate of water delivery. Table 3 shows the water delivery rates that would be required for the minimum and maximum steam delivery rates for three different tubes of three sizes with an assumed tube wall thickness of $3 \mathrm{~mm}$.

Table 3 Water delivery rates for test tube diameters

\begin{tabular}{|c|c|c|c|}
\hline \multirow{2}{*}{$\begin{array}{l}\text { Tube dimensions }(\mathrm{mm}) \\
\text { Outer / Inner diameter }\end{array}$} & \multirow{2}{*}{$\begin{array}{l}\text { Tube cross section } \\
\qquad\left(\mathbf{m m}^{2}\right)\end{array}$} & \multicolumn{2}{|c|}{ Delivery flow rate $(\mathrm{g} / \mathrm{h})$} \\
\hline & & $\begin{array}{l}\text { For minimum flow rate } \\
\left(3.0 \mathrm{mg} \cdot \mathrm{cm}^{-2} \cdot \mathrm{s}^{-1}\right)\end{array}$ & $\begin{array}{l}\text { Maximum flow rate } \\
\left(7.0 \mathrm{mg} \cdot \mathrm{cm}^{-2} \cdot \mathrm{s}^{-1}\right)\end{array}$ \\
\hline $25.4 / 19.4$ & 295.4 & 31.9 & 74.5 \\
\hline $38.1 / 32.1$ & 808.9 & 87.4 & 203.8 \\
\hline $50.8 / 44.8$ & 1575.5 & 170.2 & 397.0 \\
\hline
\end{tabular}

Therefore if a 50mm tube were chosen the pump needed to be capable of supplying a maximum of $397 \mathrm{~g} / \mathrm{h}$ water to the steam generator.

An air driven metering pump was chosen for the water supply pump. This pump was chosen because the pumping rate and volume can be controlled using manual adjustments that are amenable to a hot cell manipulator and because it does not have any electronic circuitry or components that can be damaged by radiation.

\section{Water reservoir}

For an out-of-cell test system, water can be added to the reservoir whenever necessary. In a hot cell, addition of water to the reservoir is more difficult. Consequently, the reservoir providing water for steam generation needed to be large enough to hold the volume of water that would be used at the maximum flow rate for the maximum test duration in the largest furnace tube that might be used. Table 4 shows the volume of water that would be required for three tube sizes at a flow rate of $7.0 \mathrm{mg} \cdot \mathrm{cm}^{-2} \cdot \mathrm{s}^{-1}$ and for test durations of 8,24 and $72 \mathrm{~h}$.

Table 4 Water volume requirements if system operates with $100 \%$ steam at the maximum design flow rate.

\begin{tabular}{cccc}
\hline Tube dimensions (mm) & \multicolumn{3}{c}{ Maximum volume of water (liters) } \\
\cline { 2 - 4 } Outer / Inner diameter & $\mathbf{8 ~ h}$ & $\mathbf{2 4} \mathbf{~ h}$ & $\mathbf{7 2 ~ \mathbf { ~ }}$ \\
\hline 25.4 / 19.4 & 0.6 & 1.8 & 5.4 \\
38.1 / 32.1 & 1.6 & 4.9 & 14.7 \\
50.8 / 44.8 & 3.2 & 9.5 & 28.6 \\
\hline
\end{tabular}

An additional requirement in the hot cell is that cell can't contain more than 10 liters of water at a time. Consequently, unless a $25.4 \mathrm{~mm}$ tube is selected, a waiver will have to be requested to allow a reservoir of more than 10 liters or arrangements will have to be made to permit refilling of the reservoir during longer tests and/or tests with high flow requirements.

\section{Steam Generator}

Generation of steam is accomplished by pumping the water from the reservoir into a $1 / 2$ " diameter stainless steel tube that goes through a furnace. The desired outlet steam is $300^{\circ} \mathrm{C}$ and limited by the materials of the steam generator and the valves following the steam generator. A single-stage, resistance heated furnace that has the heat output capable of converting the water to steam at $\sim 300^{\circ} \mathrm{C}$ was chosen. Figure 10 shows a photo of the steam generator and the low temperature steam delivery lines. 


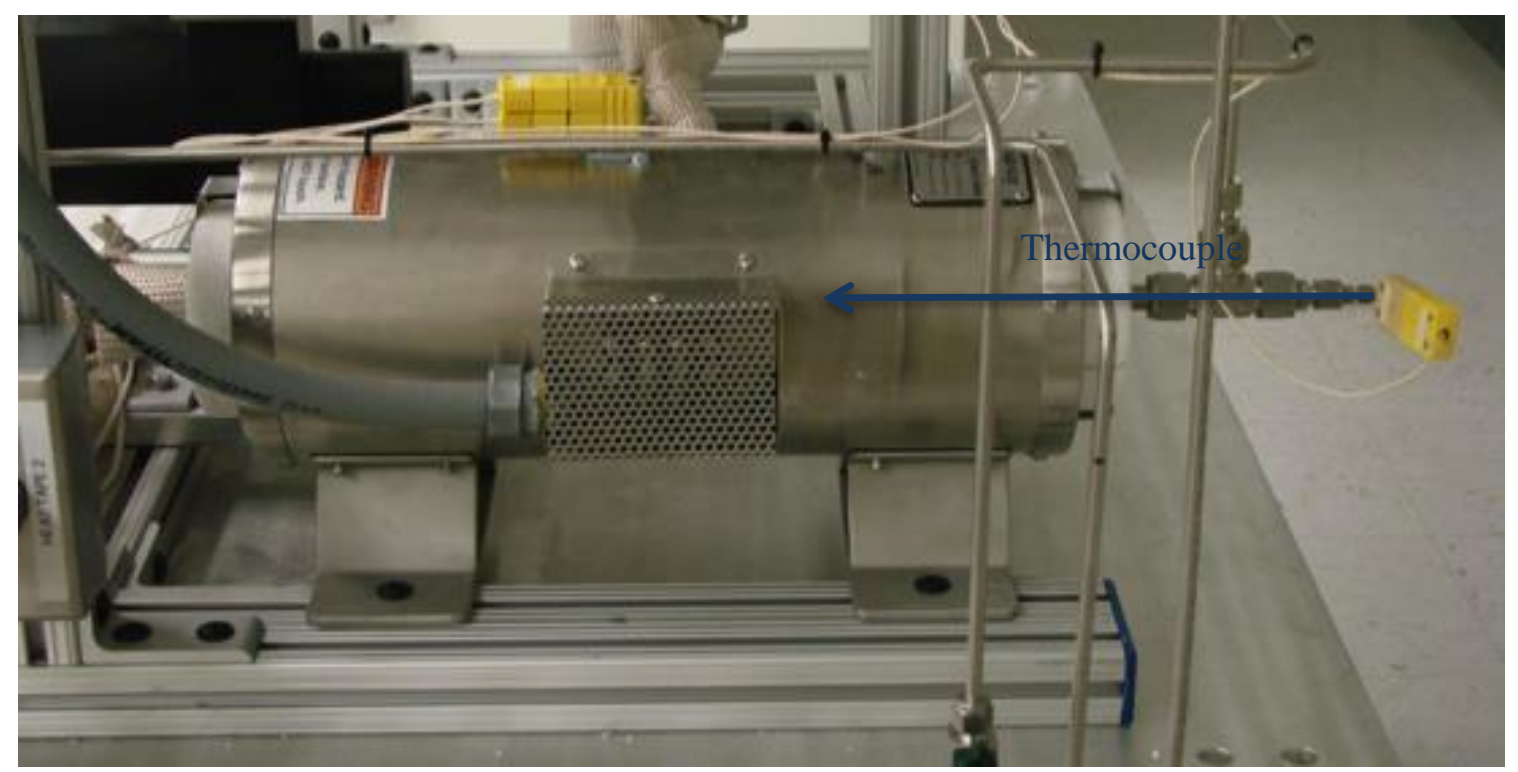

Figure 10 Steam generator and low temperature steam delivery lines

A thermocouple extends into the center of the stainless steel steam generator tube and measures the temperature of the steam being generated. It also provides one input to the emergency shutdown system to prevent overheating that can cause damage to low temperature steam valves. The safety system will be described in Section 4.1.1.1.

\section{Low temperature steam delivery lines and valves}

The steam line from the furnace is split into two streams at a tee; one feeding the DBA test module and one supplying the BDBA test module. As mentioned previously the outlet temperature of the steam generator is limited by the temperature capability of the seals of the valves controlling the direction of the steam supply. These valves are pneumatically activated because no electronic circuits will operate in the hot cell area.

Normally-closed pneumatically operated ball valves were chosen for this application and can be operated using switches on the control panel or by the LabView software during emergency shutdowns. In addition to being designed for temperatures of at least $300^{\circ} \mathrm{C}$, the seals also must be fabricated of a material that is not subject to degradation in a radiation field.

The $12.7 \mathrm{~mm}(1 / 2$ ") diameter stainless steel gas lines from the furnace to the test modules are wrapped with heat tape and thermal insulation in order to maintain the steam at $\sim 300^{\circ} \mathrm{C}$. This heat-traced and insulated steam supply line delivers low temperature steam to the assembly at the bottom of the high temperature furnaces of the BDBA module, Figure 11.

This assembly is primarily intended to deliver the test steam to the test tube, but it also includes a ball valve that can be opened, when the steam delivery system is not operating, in order to retrieve any portion of test samples that may have fallen to the bottom of the BDBA reaction tube (see Figure 11). 


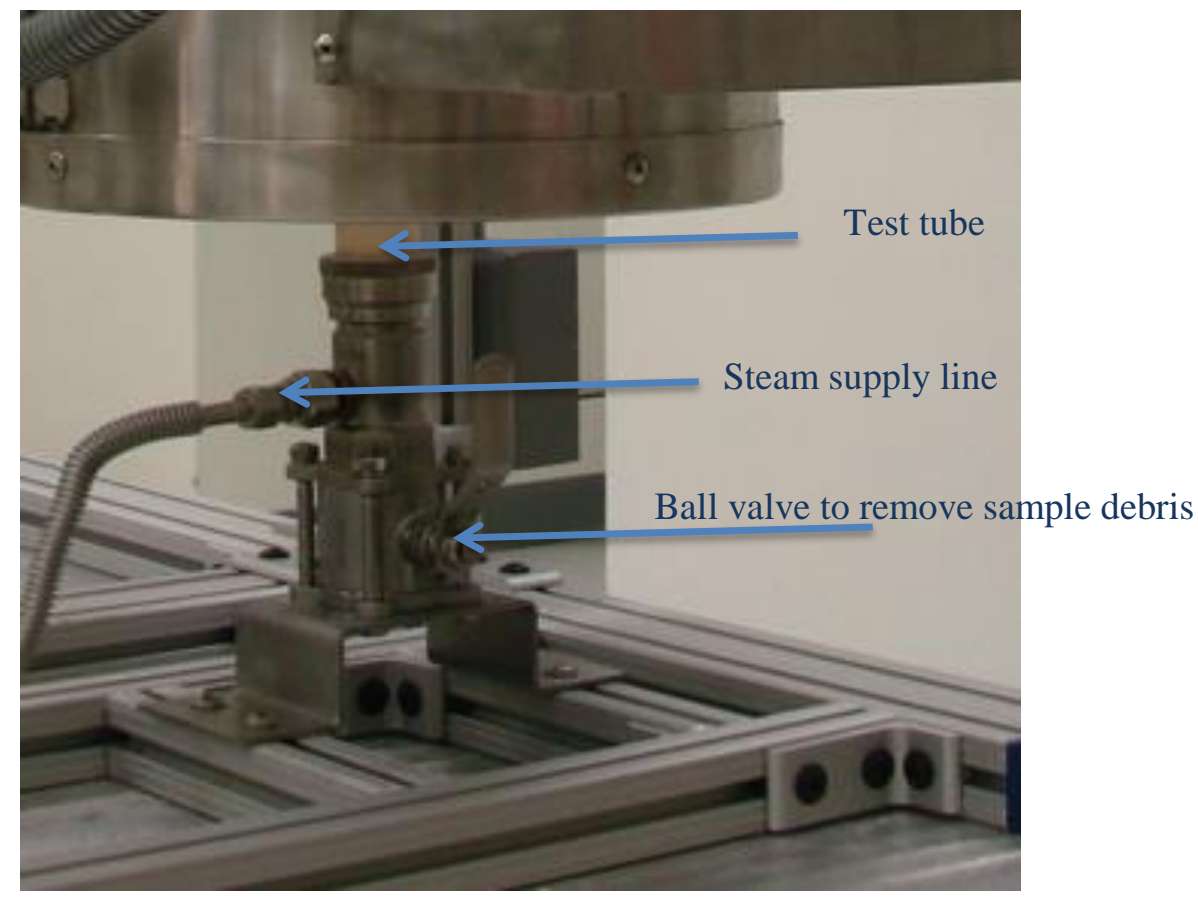

Figure 11 Gas line fittings at bottom of furnace with ball valve

\section{Test tube}

The test tube design is driven by the sample size, manufacturability and steam (steam/hydrogen) flow rates required. The sample sizes, possible tube sizes and steam flow rates are mentioned above. The high design temperature of $>1600^{\circ} \mathrm{C}$ placed a great limitation on the material to be used for the test tube.

Taking these requirements into account, a test tube of $38.1 \mathrm{~mm}\left(1 \frac{1 / 2 ")}{}\right)$ OD and $86.4 \mathrm{~cm}(34$ ") long tube made from high purity $(99.8 \%)$ alumina was chosen. This size and material are a compromise between having adequate space for samples being exposed in the tube and the limits of pumping and delivery requirements for the steam generating components.

Other options for the reaction tube are a sapphire single crystal alumina tube or high-purity zirconia. The sapphire would be transparent and would have a somewhat higher thermal conductivity than the alumina tube. However, sapphire tube manufacturers are limited in the size and length of tubes and such a tube may be significantly more expensive. For operation at $1700^{\circ} \mathrm{C}$, zirconia is preferable because alumina reacts with steam to form an aluminum hydroxide. This compound then can react with a Si-based specimen to form a low melting point reaction product. Low purity zirconia (with intentional or unintentional alumina present) was found to cause the same problem at $1700^{\circ} \mathrm{C}$.

\section{Hydrogen supply}

The gas delivery system was designed for use with a steam-hydrogen mix that contains up to $50 \%$ hydrogen. The rate at which hydrogen can be used is defined by the rate at which the waste gas can be removed. The rate of hydrogen flow through the test module is limited to $1 \%$ of the total gas being removed by the exhaust system. To date, the modules have not been operated with steam-hydrogen gas mixtures as hydrogen was not found to impact the steam oxidation behavior at $800^{\circ}-1200^{\circ} \mathrm{C}$ [13].

\subsubsection{High temperature test furnace system}

The high temperature test furnace system is comprised of the following major components: 
1. High temperature furnace

2. Sample holder

It interfaces with the test tube that transfers the steam through the furnace and holds the sample holder.

\section{High temperature furnace}

It was thought that heating steam from the steam generator at $300^{\circ} \mathrm{C}$ to $>1600^{\circ} \mathrm{C}$ would be difficult to control with one furnace. Therefore it was decided to install two furnace stages. For $>1600^{\circ} \mathrm{C}$ operation, the lower furnace heats the steam from $300^{\circ} \mathrm{C}$ to $\sim 1300^{\circ} \mathrm{C}$ and the second furnace from $1300^{\circ} \mathrm{C}$ to $>1600^{\circ} \mathrm{C}$. These temperatures would be adjusted depending on the test temperature.

There are very few types of heating elements that can heat a furnace to temperatures of $1500^{\circ}-1700^{\circ} \mathrm{C}$. For this system, two molybdenum disilicide, resistance heated, clamshell furnaces were chosen to create the very high temperature environment used for sample exposure (see Figure 12). The test tube extends from the gas-tight fitting below the lower furnace to the ceramic cap that fits over the furnace tube just above the upper furnace.

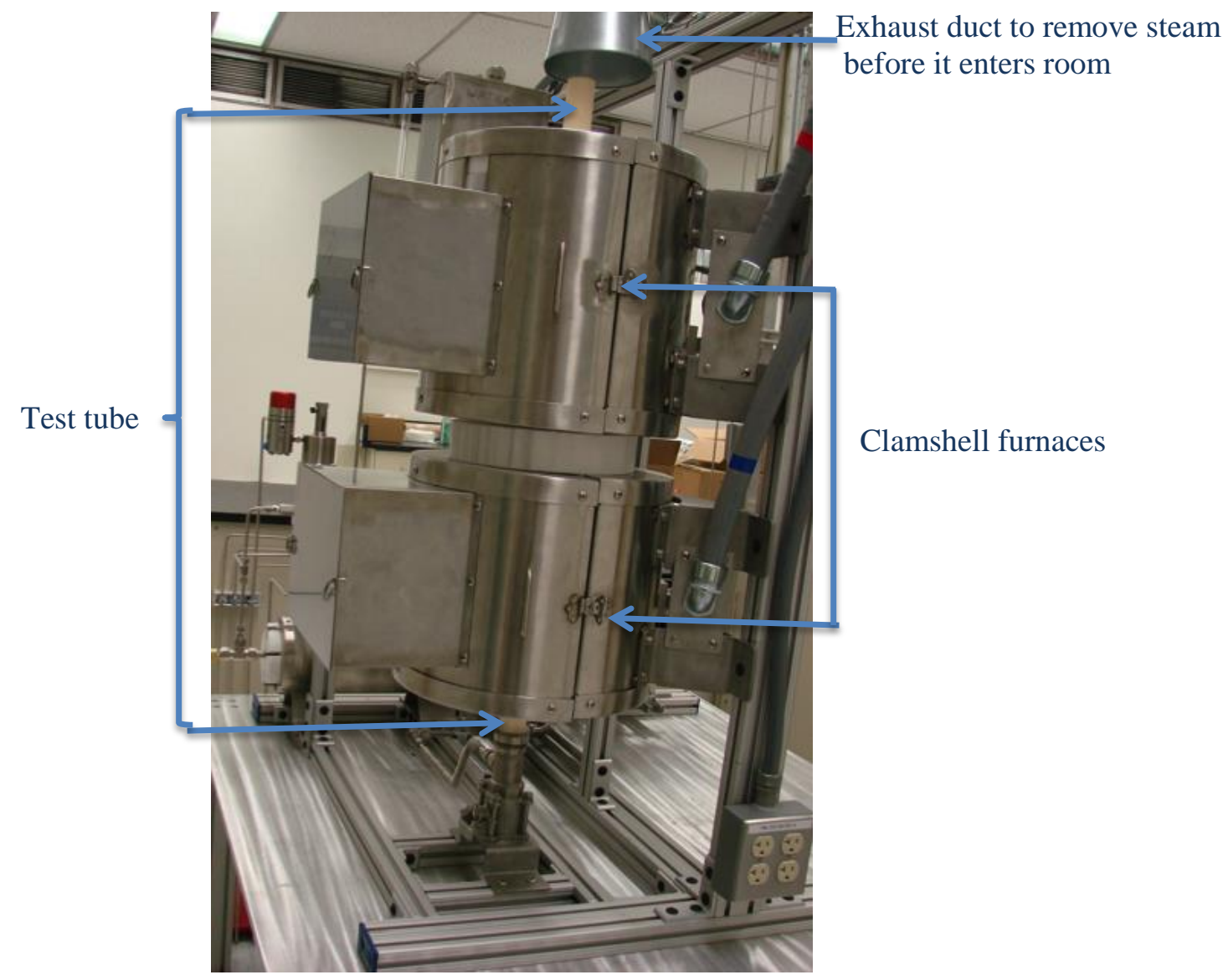

Figure 12 High temperature BDBA furnaces

\section{Sample holder}

The sample holder must be fabricated from a material that can withstand the high temperatures and the oxidation conditions. The sample holder should be of a material that will not influence the oxidation rate of the sample. Therefore it was decided to use high purity alumina to make the sample holder. 
The cap fits the top of the alumina test tube and holds the sample holder in place. It was also fabricated from high purity alumina (see Figure 13). The holder uses an alumina pin to hold the sample in place. This design has no metallic components in the steam once the steam enters the test tube.

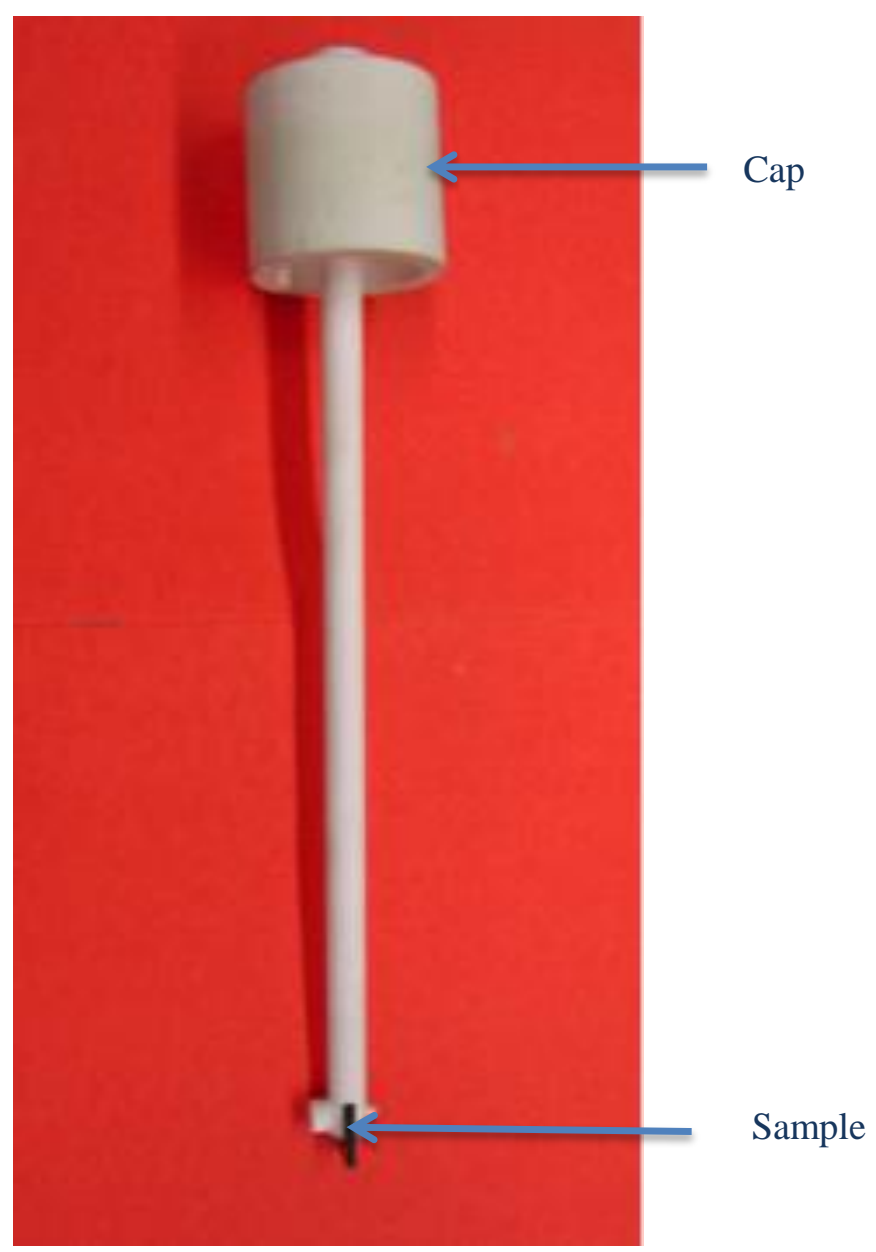

Figure 13 Alumina cap and sample holding assembly

The alumina cap on the test tube has several openings to provide access to the furnace. One hole accommodates the sample holder while two others provide access for thermocouples that measure the temperature of the gas exiting the preheating furnace and the temperature of the gas in the vicinity of the sample being tested. Other ports are used to vent the steam or steam/hydrogen gas mixture. An exhaust duct is positioned immediately above the furnace so that gas vented from the furnace tube is blended with air and pulled into the exhaust system (see Figure 12).

\subsubsection{Control system}

LabView $^{\text {TM }}$ software is used to control overall operation of the test system and to provide for emergency shutdown in the event of a number of off-normal situations. The instrument cabinet shown in Figure 14 contains the controls and associated instrumentation for operation of the test system. Honeywell controllers are used to control the furnace temperature. 


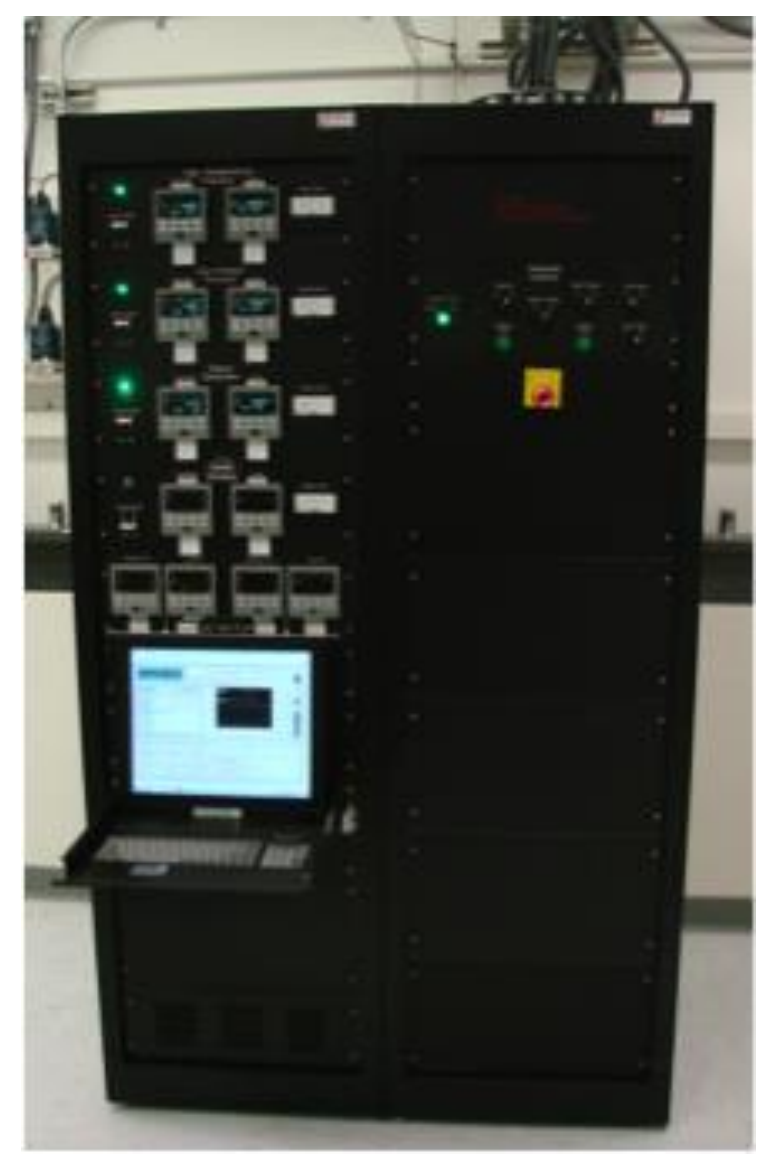

Figure 14 Instrument cabinet

\subsubsection{Safety features}

LabView $^{\mathrm{TM}}$ software is used to control the overall operation of the test module and to provide for emergency shutdown in the event of a number of off-normal situations. In the event an emergency shutdown is required, the software will turn off power to all the furnaces, turn off power to local heaters on the gas lines, stop the water pump by interrupting air flow that drives the pump, initiate flow of an argon gas purge of the delivery lines and stop flow of hydrogen gas if it is being used.

Events that would result in a system shutdown include:

1. Detection of leaking hydrogen

2. Indication of a loss of exhaust flow

3. A furnace temperature outside the selected limits

4. Excessive temperature excursions of the heated and insulated gas lines.

5. Too low a temperature in the steam generating furnace

Indication of hydrogen leakage from the test system would be accomplished by the hydrogen detector shown in Figure 15, which is mounted above the test furnaces in a position where it would detect any significant amount of hydrogen leakage. The presence of hydrogen above a predetermined concentration would result in a signal to the control system that would initiate a system shutdown, which would include closing the valve on the hydrogen supply line. If hydrogen gas was provided from high-pressure cylinders, those cylinders would be located in a flammable gas cabinet. If a hydrogen generator was used, a system shutdown would involve turning off power to the generator. 


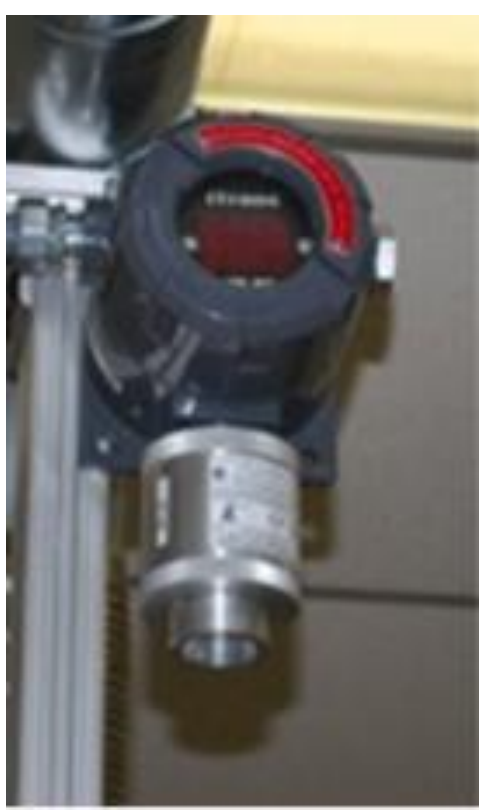

Figure 15 Hydrogen sensor

Indication of a loss of exhaust flow would be provided through a signal from the pressure differential switch that is shown in Figure 16. This switch compares the pressure in the exhaust system to the atmospheric pressure in the room. If the difference is not greater than a selected amount, an indication is provided to the control system, which initiates a shutdown of the test system.

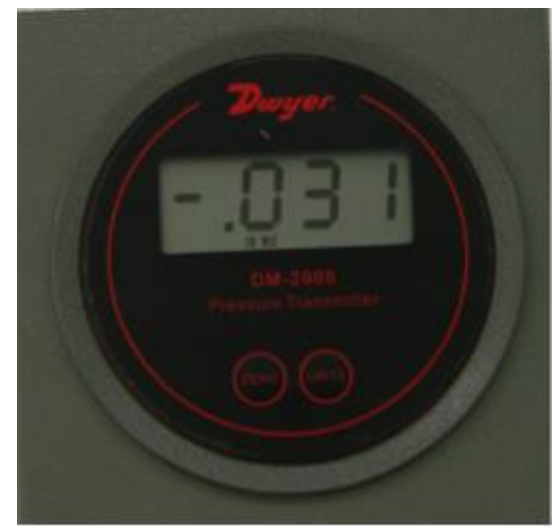

Figure 16 Differential pressure sensor

Temperature alarms are set up for over and under temperature for the furnaces and steam outlet temperature. Each furnace contains two thermocouples. A Honeywell over temperature controller monitors the second over temperature thermocouple to make sure the furnace is not damaged by overheating in case the primary control thermocouple fails.

A flammable gas cabinet was installed to contain the hydrogen gas cylinder. 


\subsubsection{DBA (or LOCA) Module}

A schematic drawing of the main parts of the DBA module or LOCA apparatus is shown in Figure 17. A photo of ORNL's DBA module is shown in Figure 18.

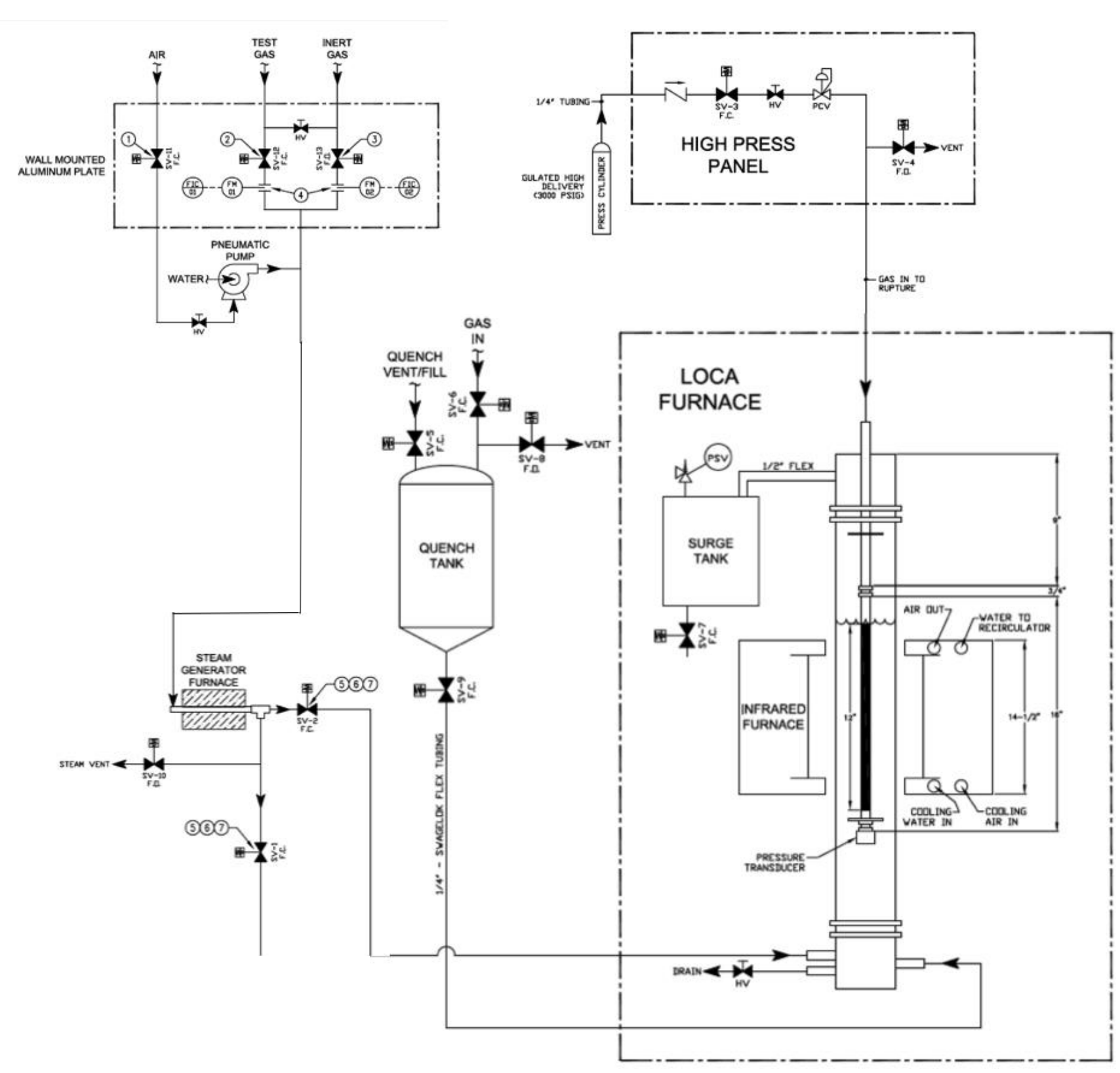

Figure 17 Schematic illustration of the DBA module. 


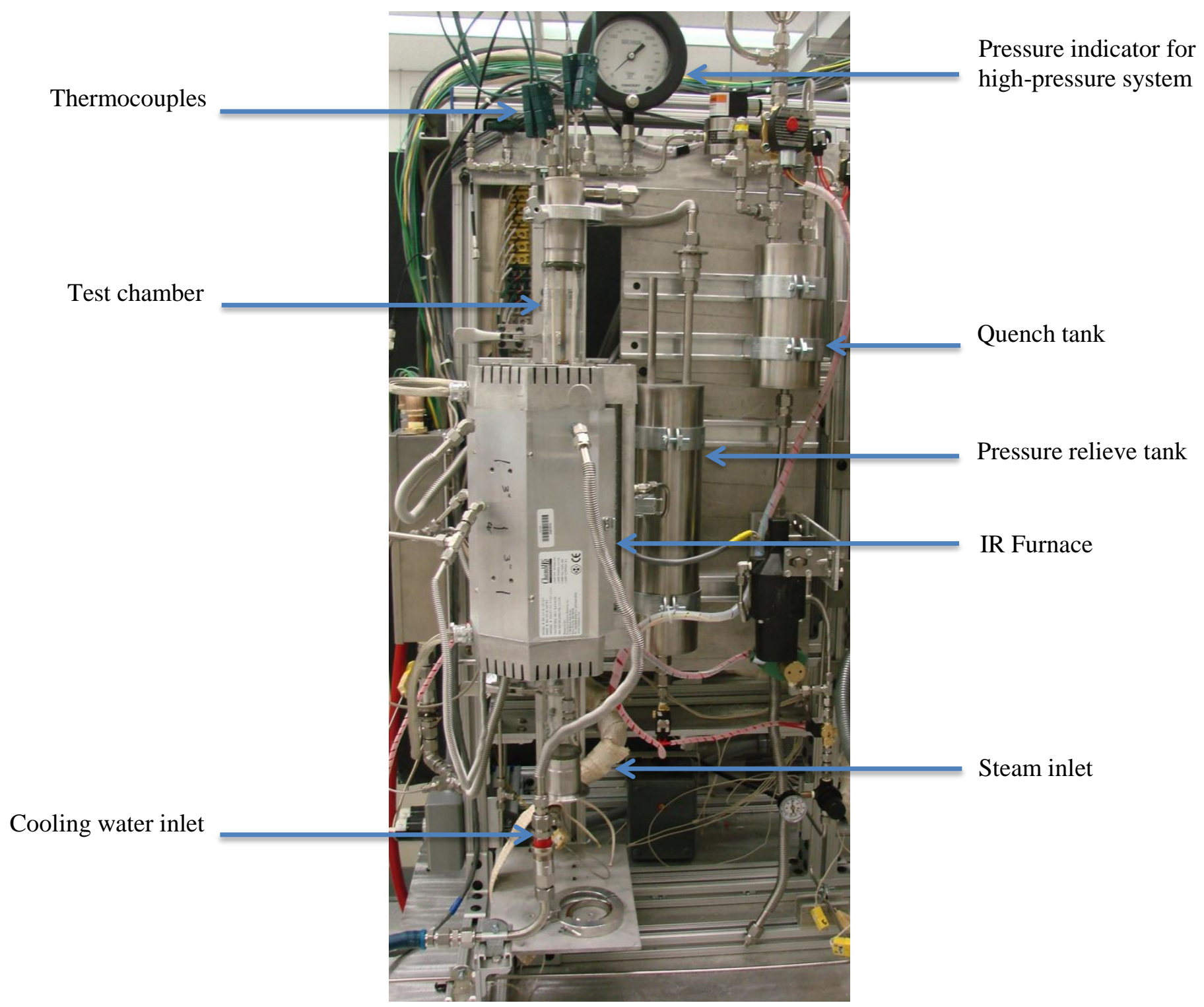

Figure 18 Overview of ORNL's out-of-cell LOCA integral test apparatus

The key components of the LOCA system include:

- Furnace

- Test chamber

- Test train

- High pressure system

- Steam delivery system

- Quench system

- Data acquisition and recording system

\subsubsection{Furnace}

An infrared (IR) furnace is used to heat the LOCA sample. The radiant-heating furnace has four vertical bulbs, reflecting inner surface, and $\sim 250 \mathrm{~mm}$ long uniform heating zone. LOCA integral tests are conducted with $300 \mathrm{~mm}$ long tube specimens initially under high internal pressure ( 8 MPa), which 
requires connection to a high-pressure Ar gas line, along with top and bottom pressure transducers. The IR furnace has the capacity to heat steam at a flow rate of $\geq 7.0 \mathrm{mg} / \mathrm{cm}^{2}$, and has a cooling system for water and air-cooling of the furnace during the LOCA tests.

\subsubsection{Test chamber}

The test chamber consists of a quartz tube (47 mm ID and $50 \mathrm{~mm}$ OD). Following oxidation and slowcooling phases, steam flow is turned off, and quench water is introduced through the bottom to give very rapid sample cooling of the specimen to $70-100^{\circ} \mathrm{C}$ at the desired time and temperature during cooling.

The quartz tube encasing the test train provides an enclosed volume for steam flow and water quench, both of which are introduced through the bottom of the unit. The test train is centered within the quartz tube by means of two spacer disks. Swagelok fittings are used above and below the specimen to connect to the high-pressure gas line and pressure gauges,

The sample temperature is measured with a thermocouple attached on the rod specimen approximately 50 $\mathrm{mm}$ above the axial mid plane. Typically, the sample is internally pressurized with Ar gas and heated in the quartz tube test chamber with a flowing steam environment. A test chamber with a tube sample is shown in Figure 19.

\subsubsection{High pressure system}

The high-pressure system consists of a high-pressure Ar line, a high-pressure control valve, and two pressure gauges. It is used to provide internal high pressure for LOCA internal tests and to monitor the pressure change during the ballooning and burst phase of the LOCA tests. As shown in Figure 17, two pressure transducers are used at the bottom and at the top of the LOCA specimen to measure the pressure.

\subsubsection{Steam delivery system}

The steam supply is shared with that of the BDBA module and information can be found in section 4.1.1.1. The low temperature steam delivery valve directs the steam to the BDBA or the DBA module. The steam enters the test chamber at the bottom of the quartz tube.

\subsubsection{Quench system}

The quench system consists of the quench tank, a valve between the tank and the test chamber and an air pressure system that pushes the water in the right amount of time into the test chamber. The volume of the quench tank is such that when emptied it will fill the quartz tube to cover the tube sample.

\subsubsection{Data acquisition and recording system}

LabView $^{\mathrm{TM}}$ software is used to control overall operation of the DBA module, as well as the data acquisition and recording. It also provides for emergency shutdown in the event of a number of offnormal situations. The instrument cabinet shown in Figure 14 also contains the controls and associated instrumentation for operation of the DBA module, which is shared with the BDBA system operation. 


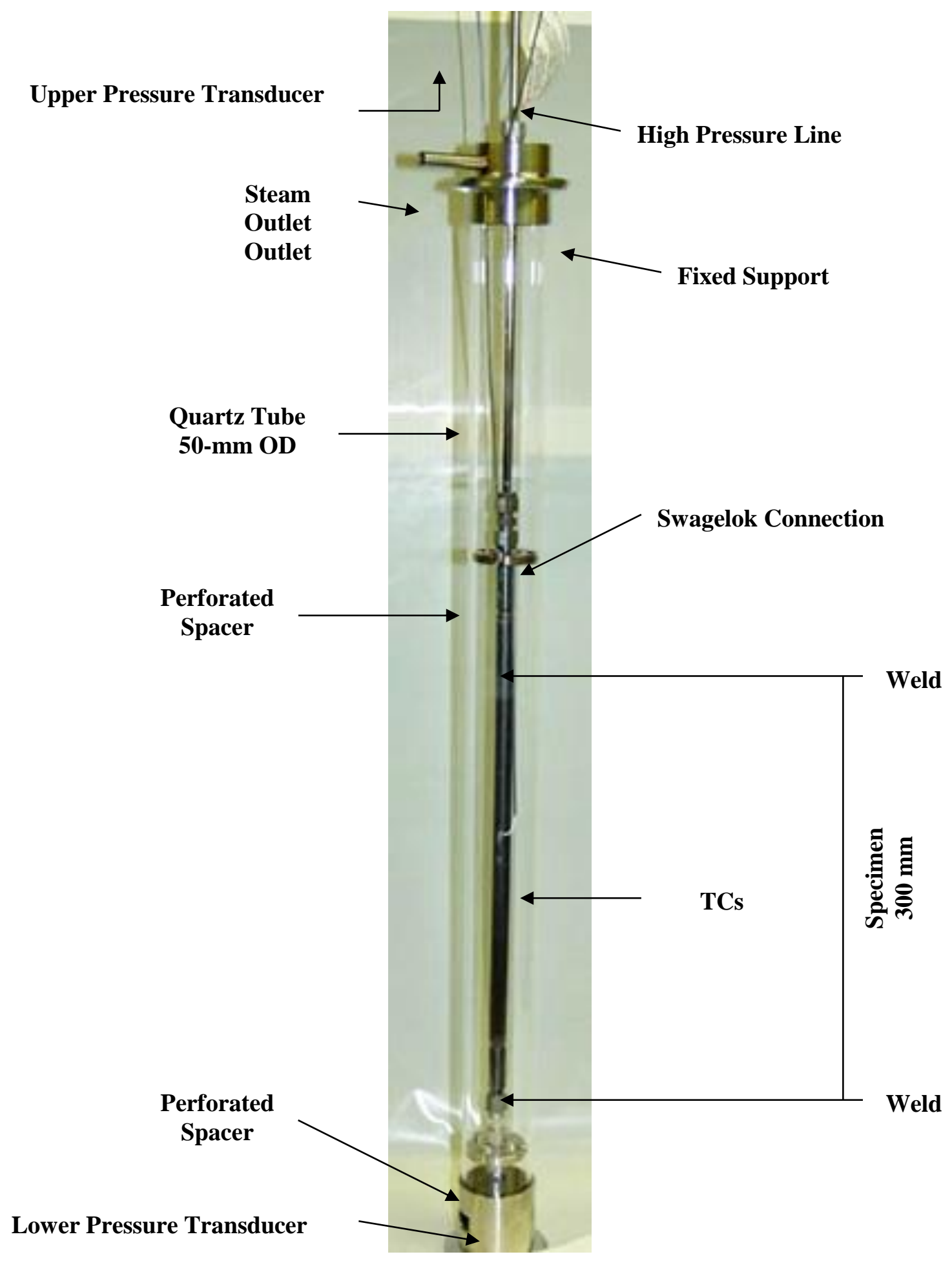

Figure 19 LOCA integral test train assembly and quartz tube. 


\subsubsection{LOCA performance}

During the out-of-cell development of the DBA module, several thermal benchmark tests were run to aid in the optimization of the apparatus and the test train for remote operation in the hot cell. These tests were conducted with specimens made from various cladding materials. For the quad-elliptic radiantfurnace, specimen bowing induced significant axial and circumferential variations in temperature. This problem was solved by supporting the test train at the top (see Fig. 19 for the test train).

The result of one out-of cell LOCA integral test is shown in Figure 20Figure 20 Temperature and pressure histories during ramp for typical out-of cell LOCA Integral Test with 9x9 Zircaloy-2 cladding specimen. This out-of cell test was performed with 9x9 Zircaloy-2 tubing at the typical LOCA test conditions shown in in the literature [4-6]: $300 \mathrm{~mm}$ cladding length, 15-mm clearance between top end-cap and pellet stack, room-temperature gauge pressure of $1200 \mathrm{psi}$, stabilization at $300^{\circ} \mathrm{C}, 5^{\circ} \mathrm{C} / \mathrm{s}$ temperature ramp in steam to a control temperature of $1200^{\circ} \mathrm{C}, 5$ minute hold time at $1200^{\circ} \mathrm{C}, 3^{\circ} \mathrm{C} / \mathrm{s} \mathrm{cool}$ down rate to $800^{\circ} \mathrm{C}$, and water quench initiated at $800^{\circ} \mathrm{C}$. Our experimental benchmark results agree with the data shown in the literature [4-6], which confirms that the ORNL DBA test module meets the design requirement. In addition to thermal benchmarking, metallographic analysis was used to verify that the oxide layers formed in steam at $\sim 1200^{\circ} \mathrm{C}$ were consistent with oxidation kinetics test results.

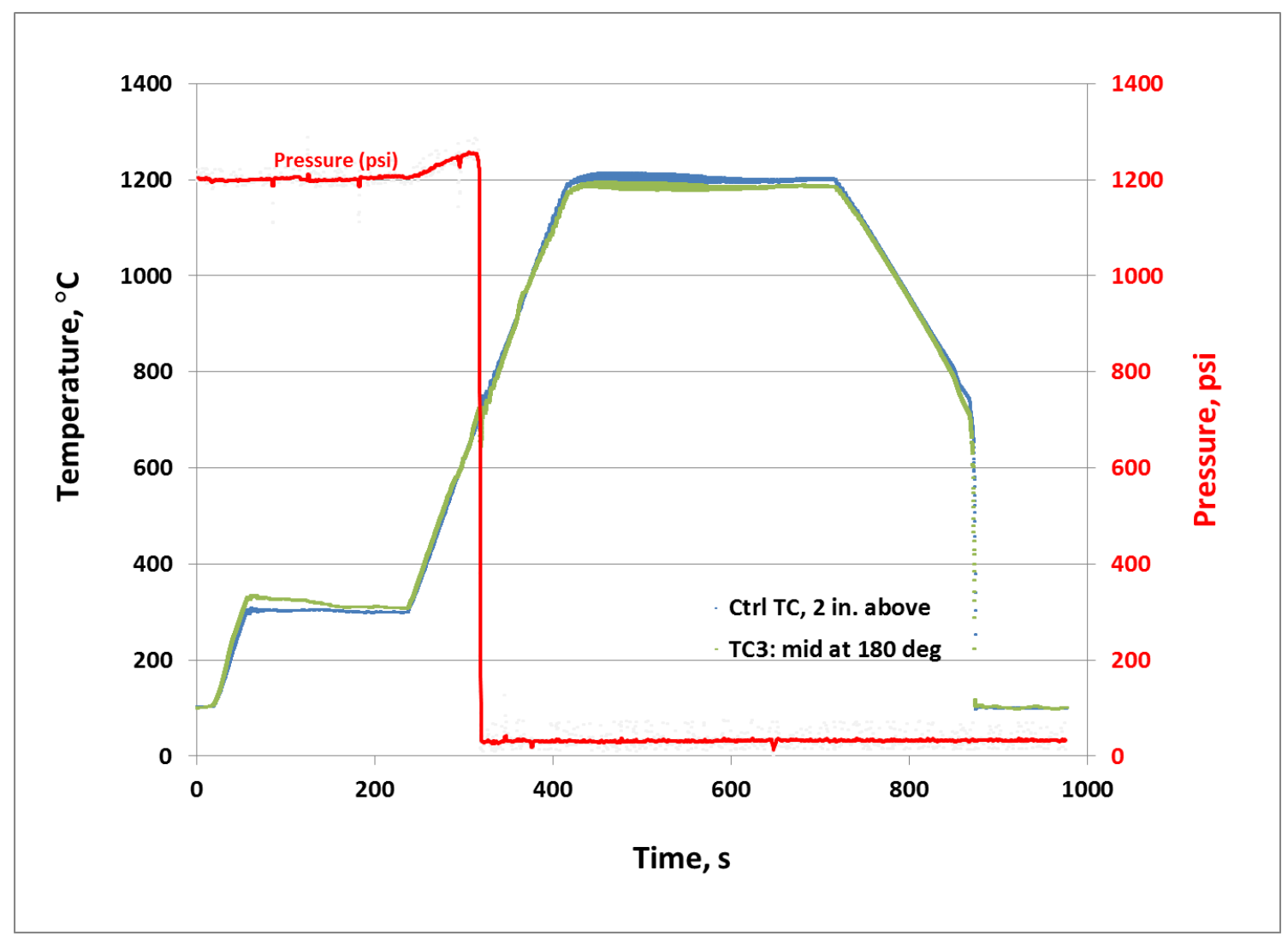

Figure 20 Temperature and pressure histories during ramp for typical out-of cell LOCA Integral Test with 9x9 Zircaloy-2 cladding specimen. 


\subsection{IN CELL MODULES}

A 3D drawing was generated for the in-cell module [12], by which all components of the in-cell system can be tracked. The 3D drawing is particularly important after the in-cell module is installed into the hot cell. The out-of-cell module did not require a 3D drawing as it can be readily repaired and modified as needed. The major components of the 3D drawing are shown in Figure 21 to Figure 23. 


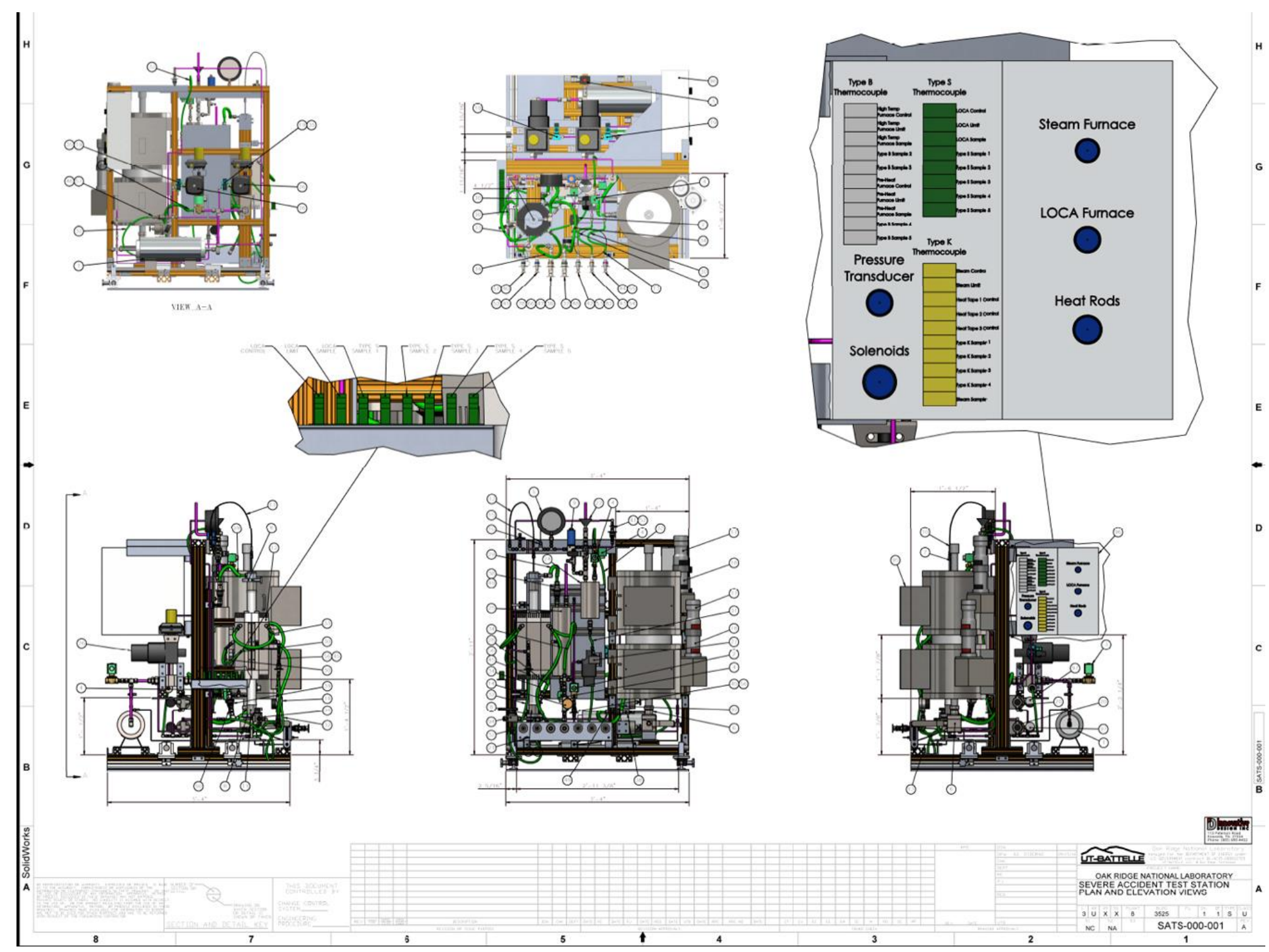

Figure 21 SATS plan and elevation views [12]. 


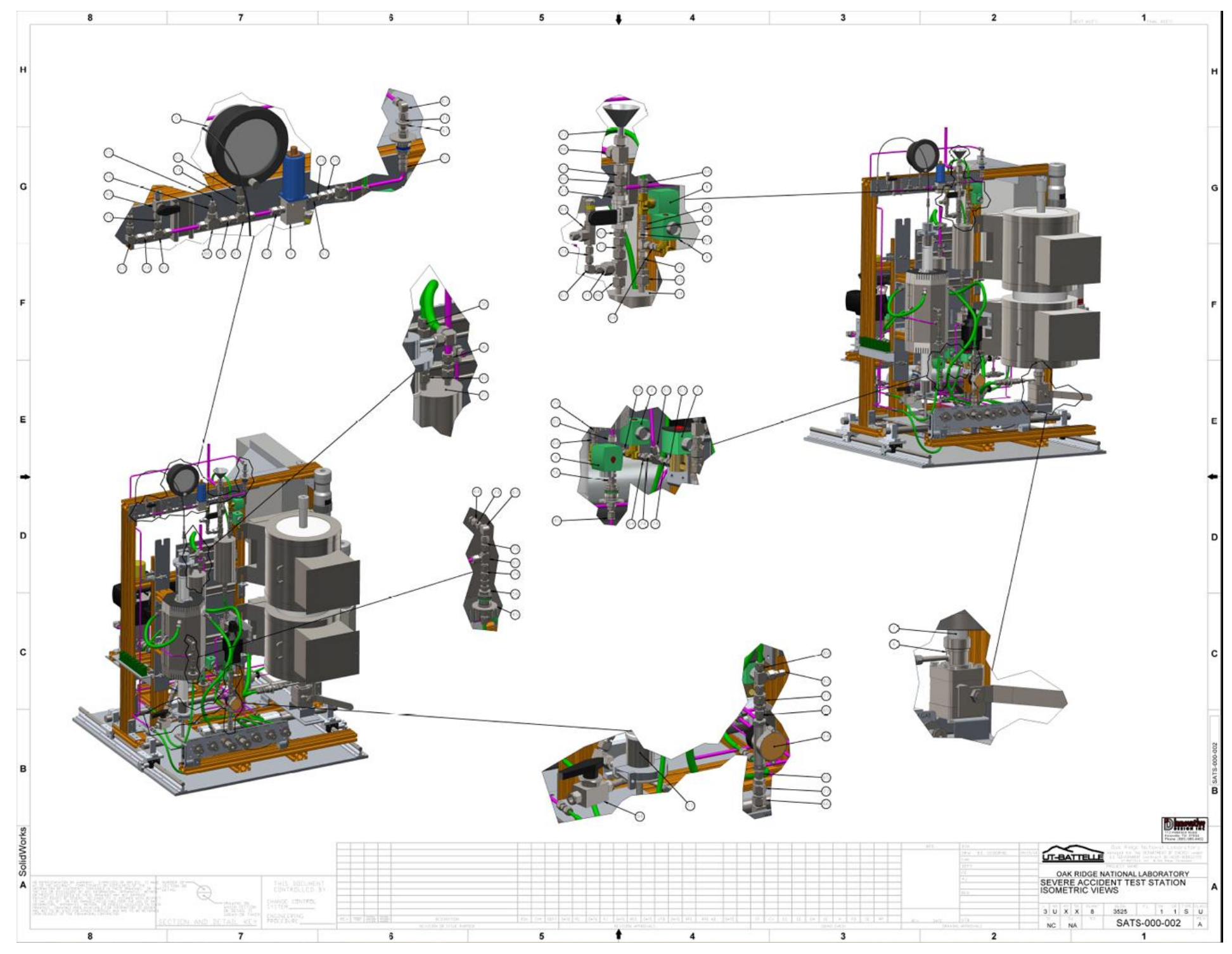

Figure 22 SATS Isometric Views 1 [12] 


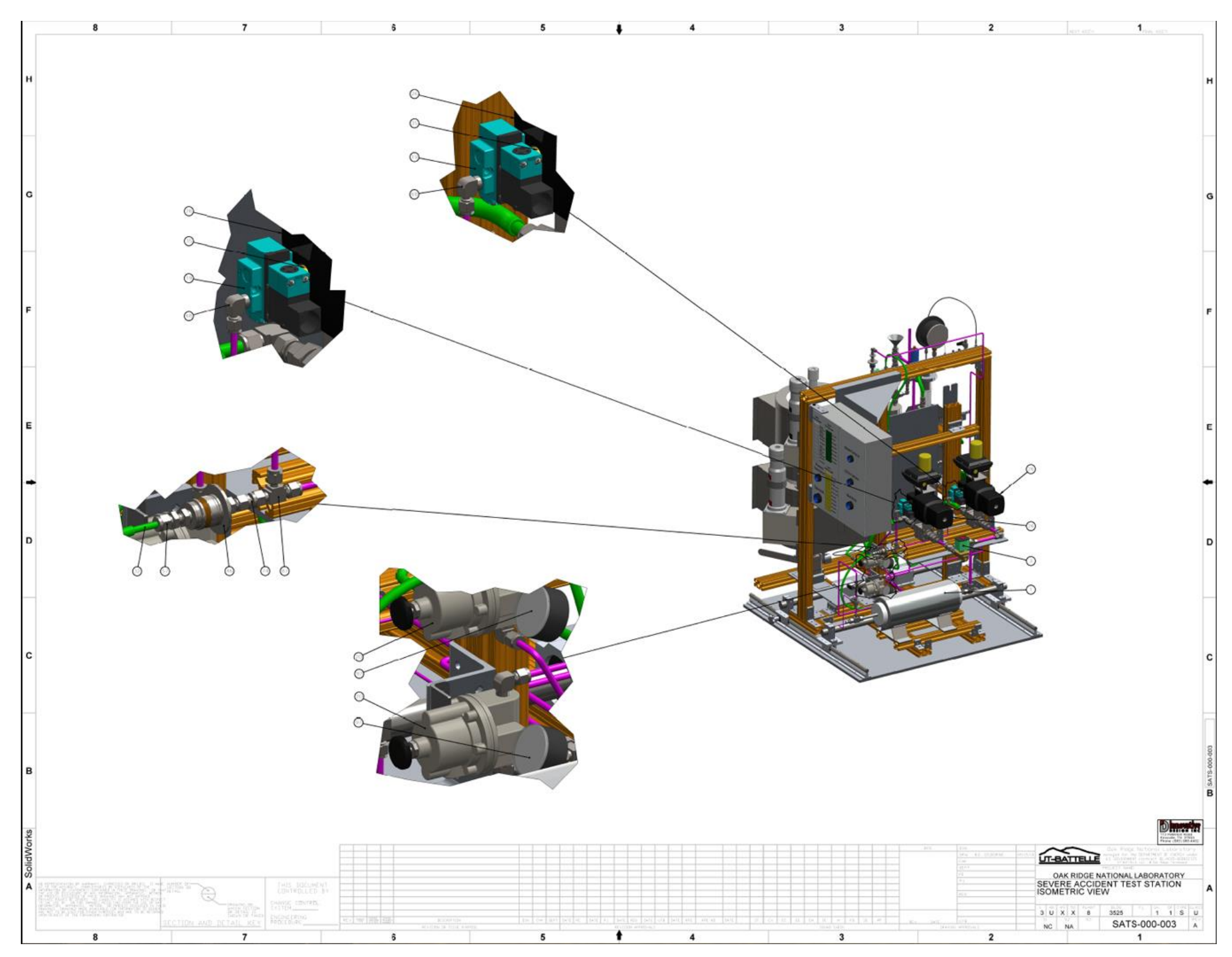

Figure 23 SATS Isometric Views 2 [12]. 


\subsubsection{BDBA Module}

The in-cell BDBA module is nearly the same as the out-of-cell module. The ex-cell module has bee extensively operated with 40 specimens run in 2013 and 82 in 2014. Minor improvements were implemented on the in-cell module based on this operating experience. These improvements are discussed in subsections below. Figure 24 shows a schematic of the BDBA module and Figure 25 shows the in cell module located in the hot cell building near the cell where it will be installed.

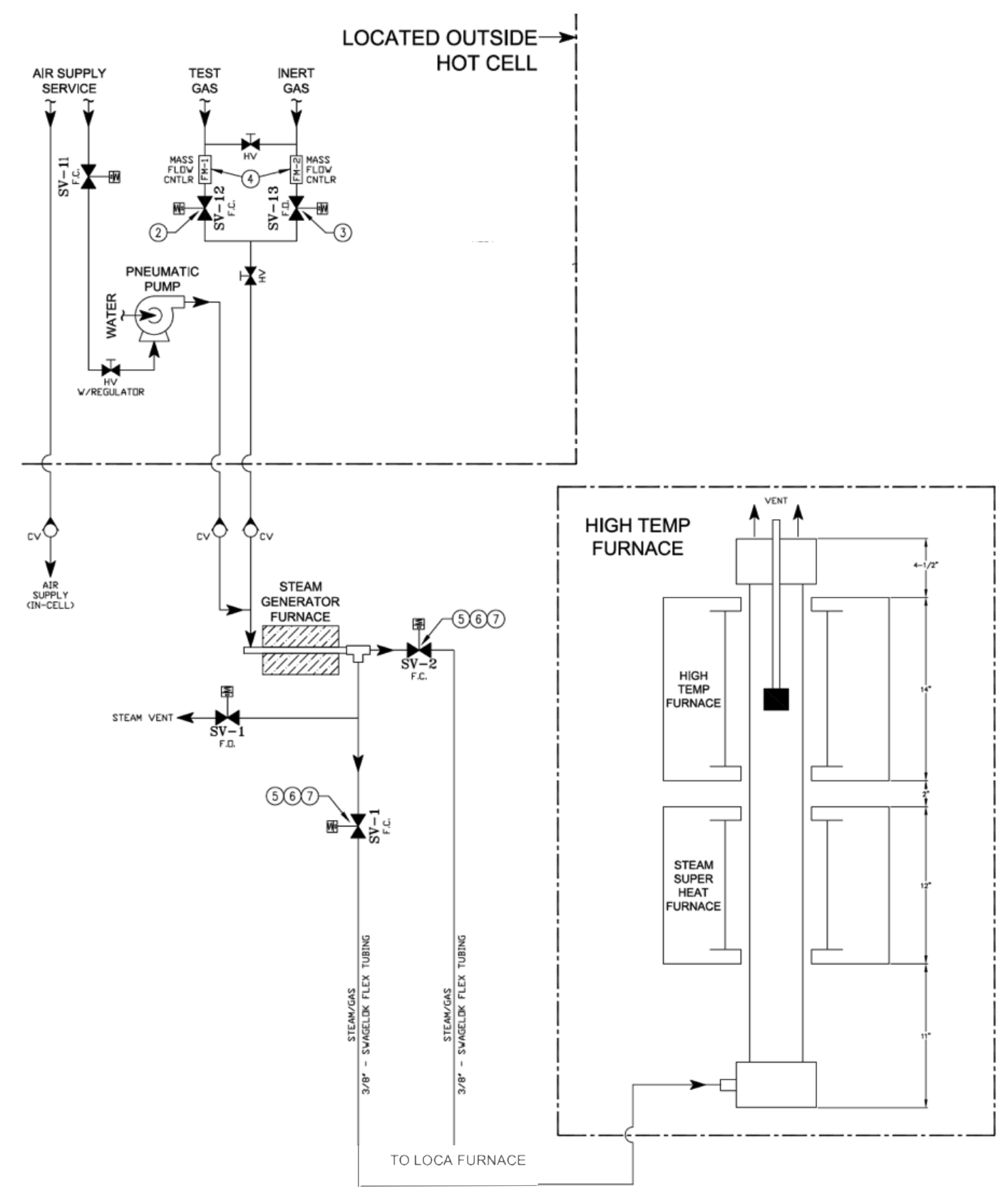

Figure 24 Schematic of BDBA in-cell module 


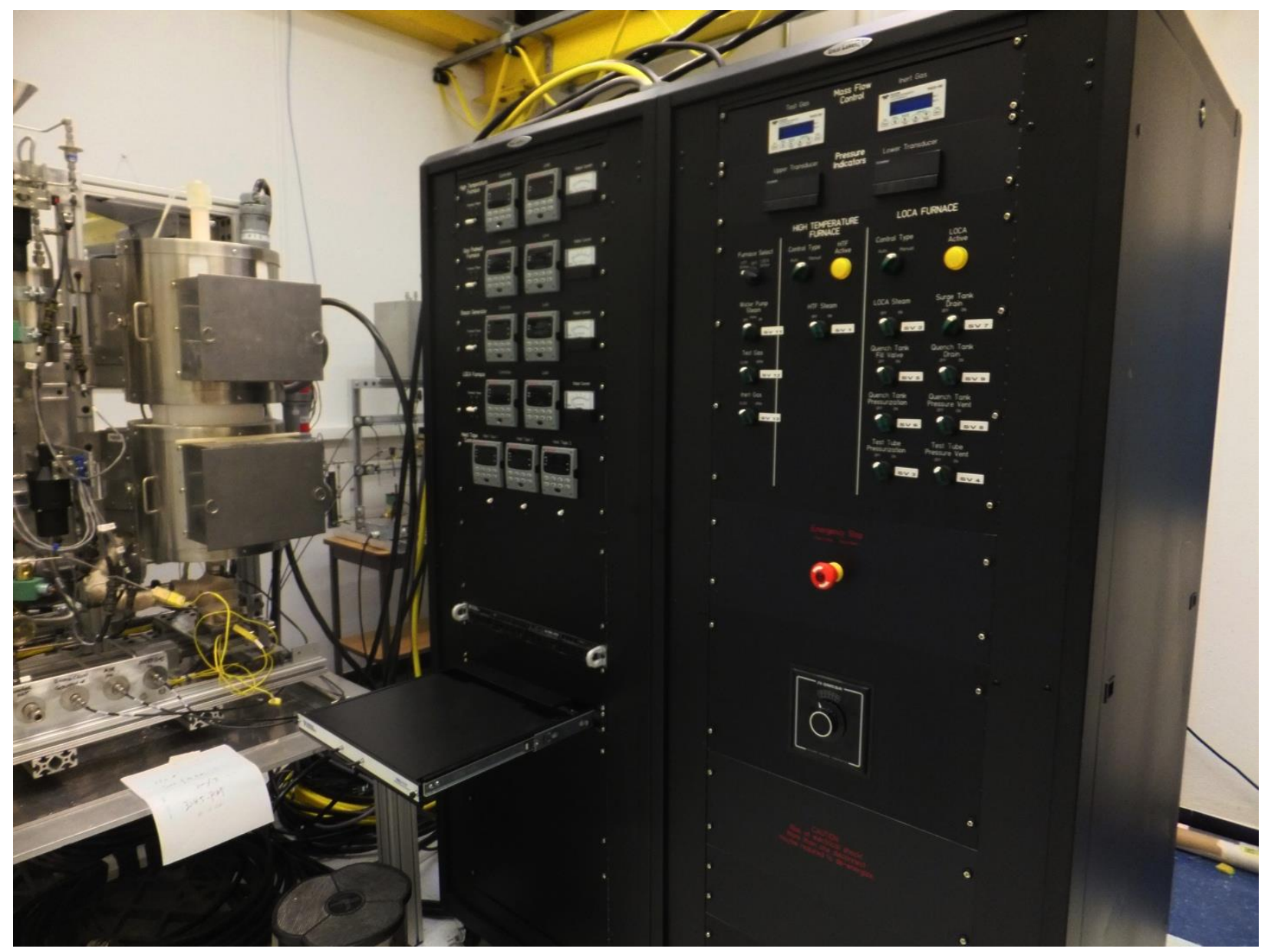

Figure 25 BDBA in-cell module located at hot cell facility

\subsubsection{Manipulator control of the module}

Certain changes have been made in the design and assembly of the high temperature furnace component of the in-cell module in order to make it more amenable to manipulator operation in the hot cell. Specifically, the power connections for the two high temperature furnaces, the mounting arrangement for these two furnaces and the connections for thermocouples, transducers and other connectors were designed to be more "manipulator friendly".

Quick connectors (Figure 26) were added for easy installation of the module, connecting out of cell piping with the in cell module. The furnace power connections for the in-cell and out-of-cell modules are shown in Figure 23. The in-cell connections were positioned so that a vertical motion would be required to connect or disconnect the furnaces while the power lines for the out-of-cell module use standard hardwire connections.

In the event one of the high temperature furnaces on the in-cell module were to become damaged or not functioning properly, the entire furnace would be replaced rather than trying to repair it using manipulators. The first step in removing a furnace would be to disconnect the power, which is made far easier with the power plug arrangement shown in Figure 23. In order to decrease the difficulty of removing a damaged furnace from the module, the brackets holding the furnaces to the frame on the incell module are slotted so that loosening four screws will permit the furnaces to be lifted straight up and 
off the frame. The differences in the furnace attachments for the out-of-cell and in-cell modules are shown in Figure 28. Figure 29 shows the panel installed on the in-cell, module to facilitate making the connections for the instrumentation and lower voltage power connections. The out-of-cell module does not utilize this panel arrangement.

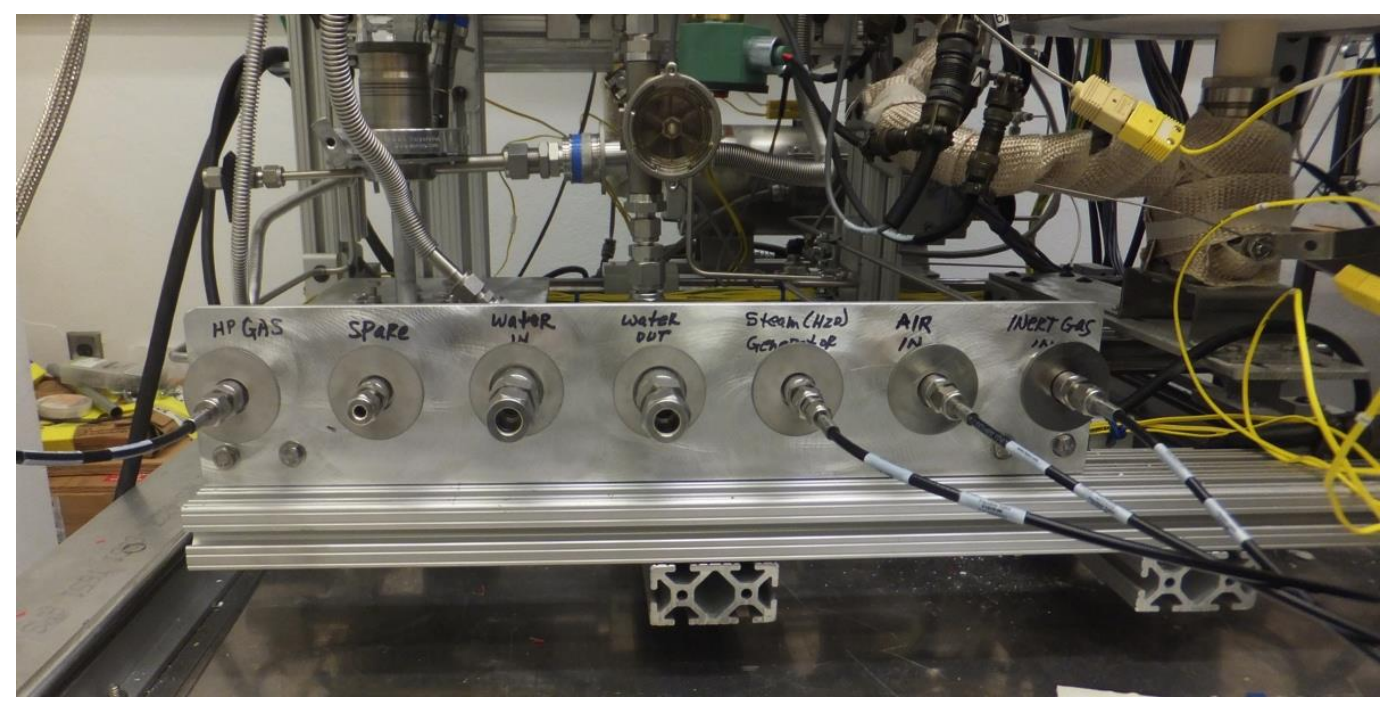

Figure 26 Quick connectors
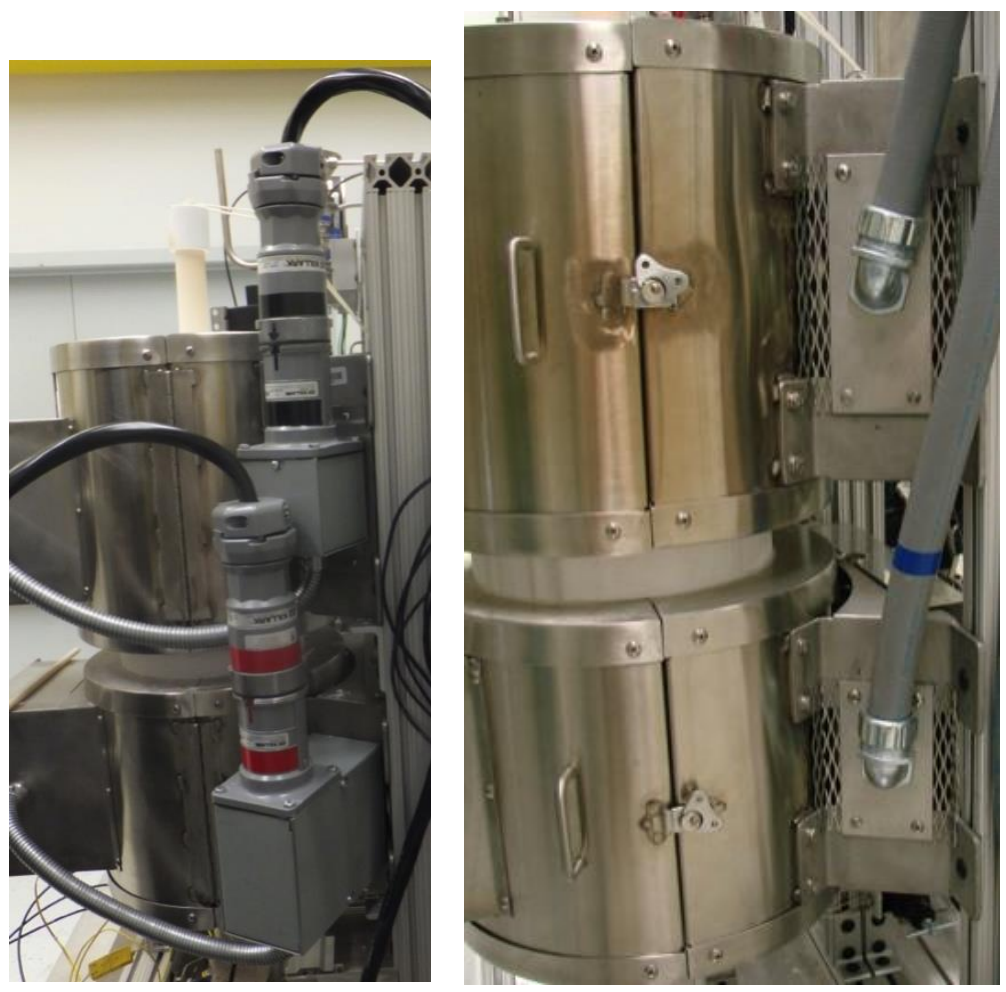

Figure 27 Power connections for the high temperature furnaces on the out-of-cell module (left) and in-cell module (right). 

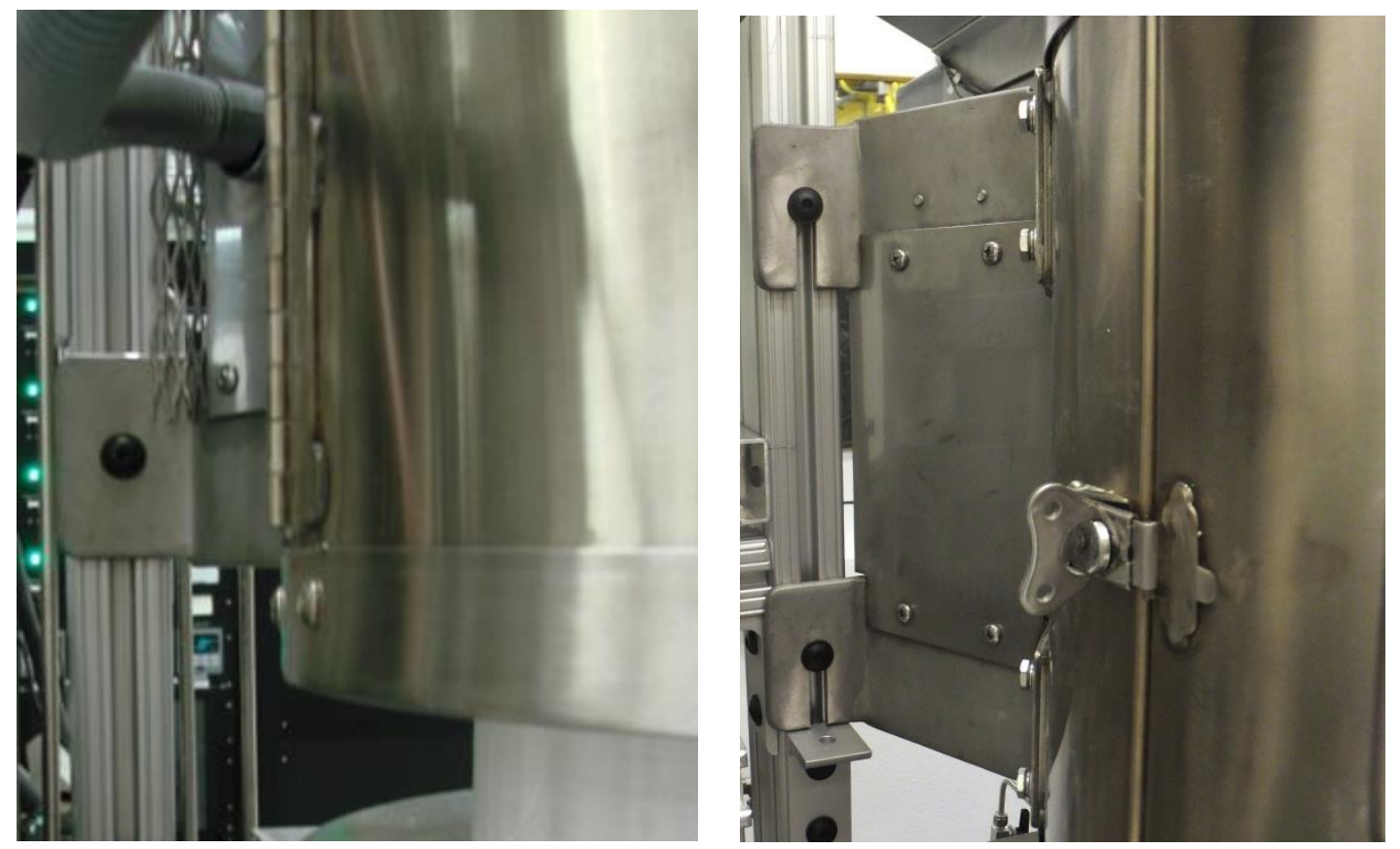

Figure 28 Furnace bracket arrangements on the out-of-cell (left) and in-cell (right) attachments for the high temperature furnaces

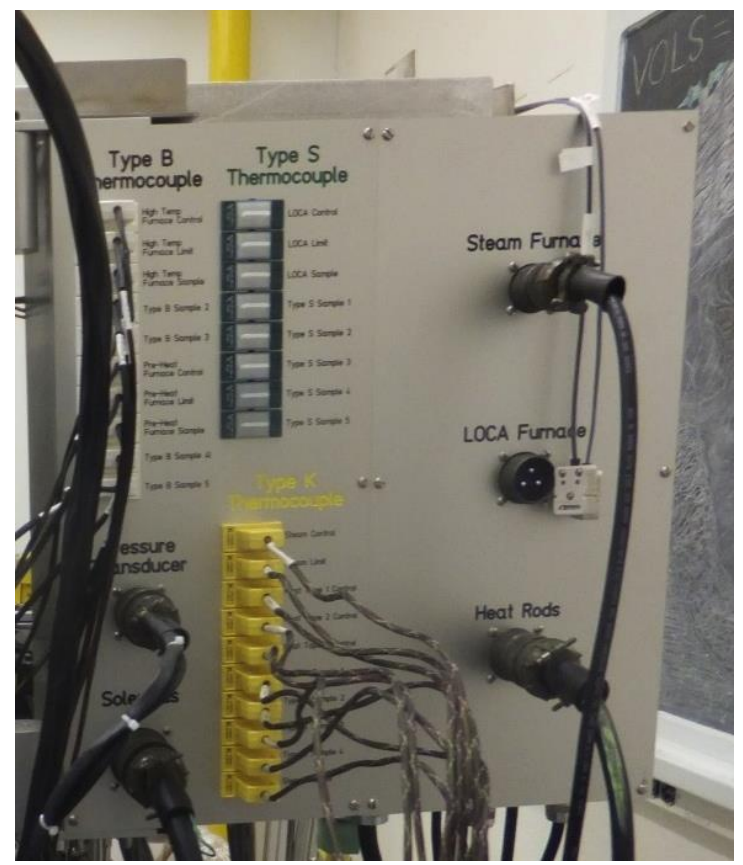

Figure 29 Connector panel on the in-cell module which facilitates connections for thermocouples, pressure transducers, solenoid valves, and other power connections. 


\subsubsection{Optimization of operation of module}

The option of picking the amount of data points to be collected, on the Lab View operating module, was updated as the LOCA (DBA) test needs very frequent data points and the BDBA test needs less frequent data collection as it is much longer test. An automation was included to stop operating and data collection when the test is completed. Screen updates were improved to allow quicker response to commands.

\subsubsection{Removing hydrogen mixture capability in hot cell}

While gas environments consisting of steam-hydrogen mixtures are possible for the out-of-cell BDBA module, introduction of hydrogen inside the hot-cell poses safety risks. Given this constraint, it is expected that the effect of hydrogen on the degradation processes of the fuel and cladding materials, if any, will be captured during the out-of-cell tests on non-irradiated specimens. Note that the large body of work to date on the high-pressure steam-hydrogen exposures has shown a very negligible hydrogen effect, if any, on the oxidation of candidate cladding alloys [13]. The effect of hydrogen on oxidation of zirconium alloys with an oxide layer on the surface has already been shown to be nonexistent [8] unless steam starvation conditions are approached [9]. In the meantime, the presence of hydrogen is known to alter (toward inhibiting) oxidation kinetics of $\mathrm{UO}_{2}$ to $\mathrm{U}_{3} \mathrm{O}_{8}$.

\subsubsection{Shielding Plugs}

Lead and alpha plugs were designed and constructed as shielding plugs between the hot cell and the operator. These plugs provide a feed through for the utilities that are needed in the cell. Figure 24 shows the components that are inside and outside of the cell. Figure 30 shows a portion of a design drawing of one of the lead-alpha plugs and Figure 31 shows the test-assembly of the shielding plug for the feed through of the power cables.

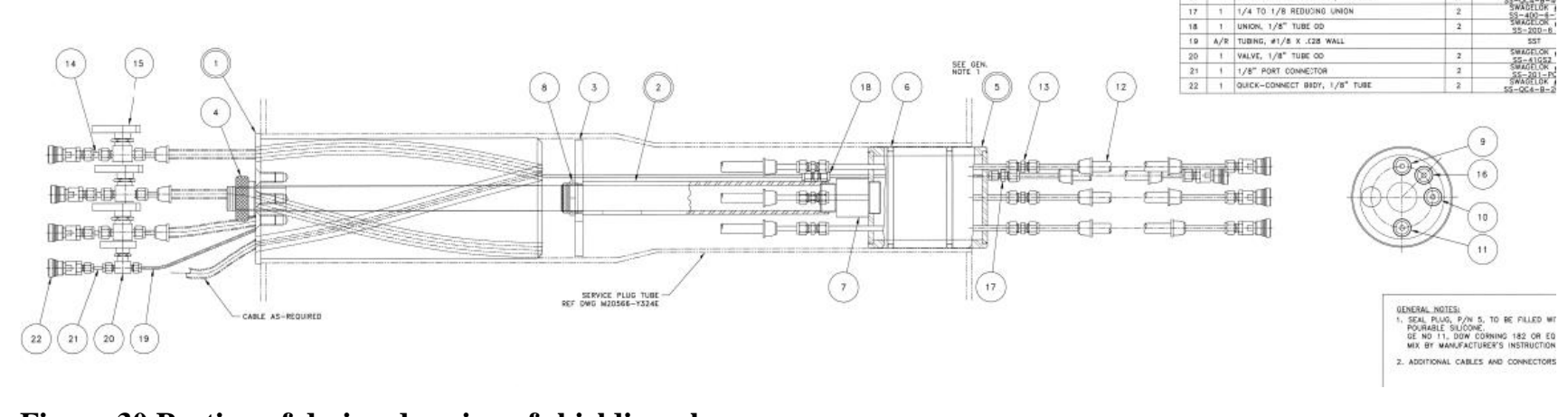

Figure 30 Portion of design drawing of shielding plug

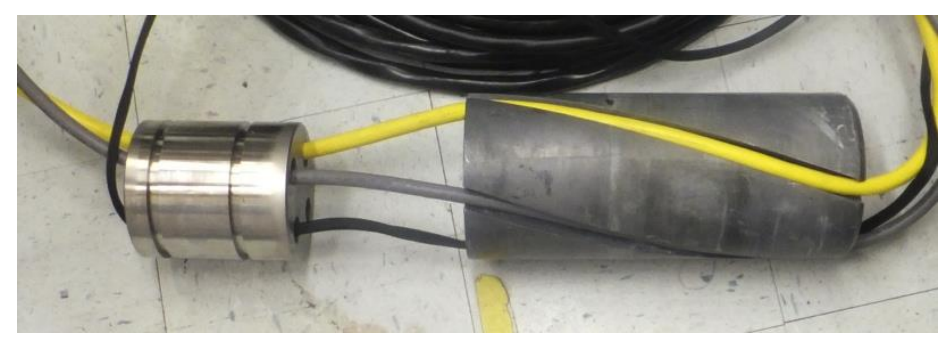

Figure 31 Shielding plug test-assembly 


\subsubsection{Safety analysis}

An operating guideline was written for the operation of the SATS at the ORNL hot cell [11]. This guideline was reviewed and approved by the facility manager, safety officer, radiation control officer and the quality control manager. This guideline was used as input to the Un-reviewed Safety Question Determination (USQD). The outcome of the evaluation of the new activity did not require the SAR to be updated as the SATS facility's operation falls within its safety requirements.

\subsubsection{In-cell and out-of cell comparison}

The in-cell high temperature furnace module, that is essentially the clone of the out-of-cell module, successfully reproduced data from the out-of-cell module. Specifically, $4 \mathrm{~h}$ exposures to a $100 \%$ steam environment were carried out for monolithic CVD-SiC (Figure 32) and APMT (FeCrAl) specimens (Figure 33) at $1700^{\circ}$ and $1450^{\circ} \mathrm{C}$, respectively. The mass loss for CVD-SiC was within the range of values previously measured by the out-of-cell module. The mass change per unit area for the APMT alloy was in excellent agreement with previous results from the out-of-cell module as well as the Rubotherm TGA unit.

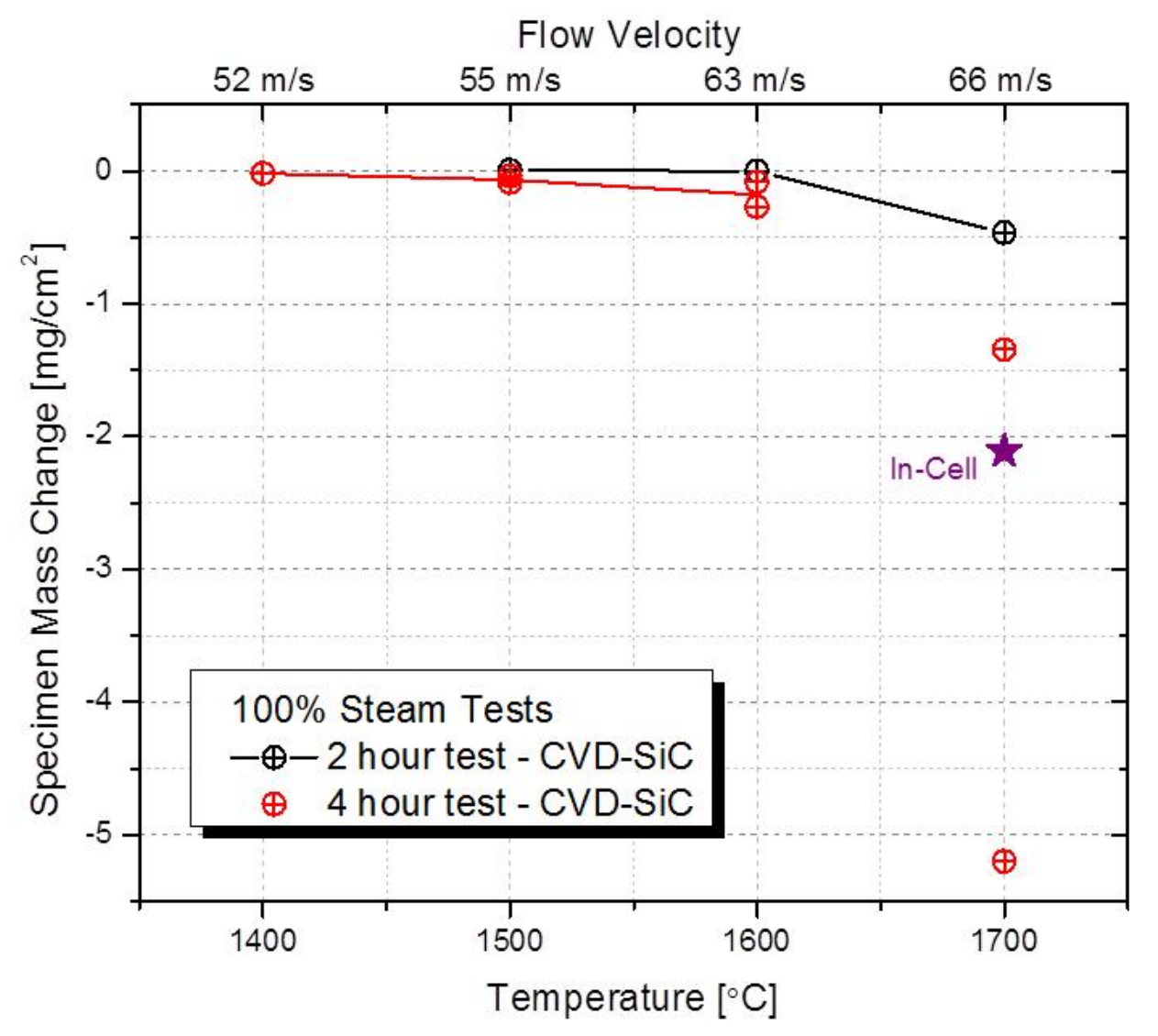

Figure $32 \mathrm{CVD}-\mathrm{SiC} 1700^{\circ} \mathrm{C} 4 \mathrm{~h}$ specimen mass change comparison between out-of-cell and in-cell modules 


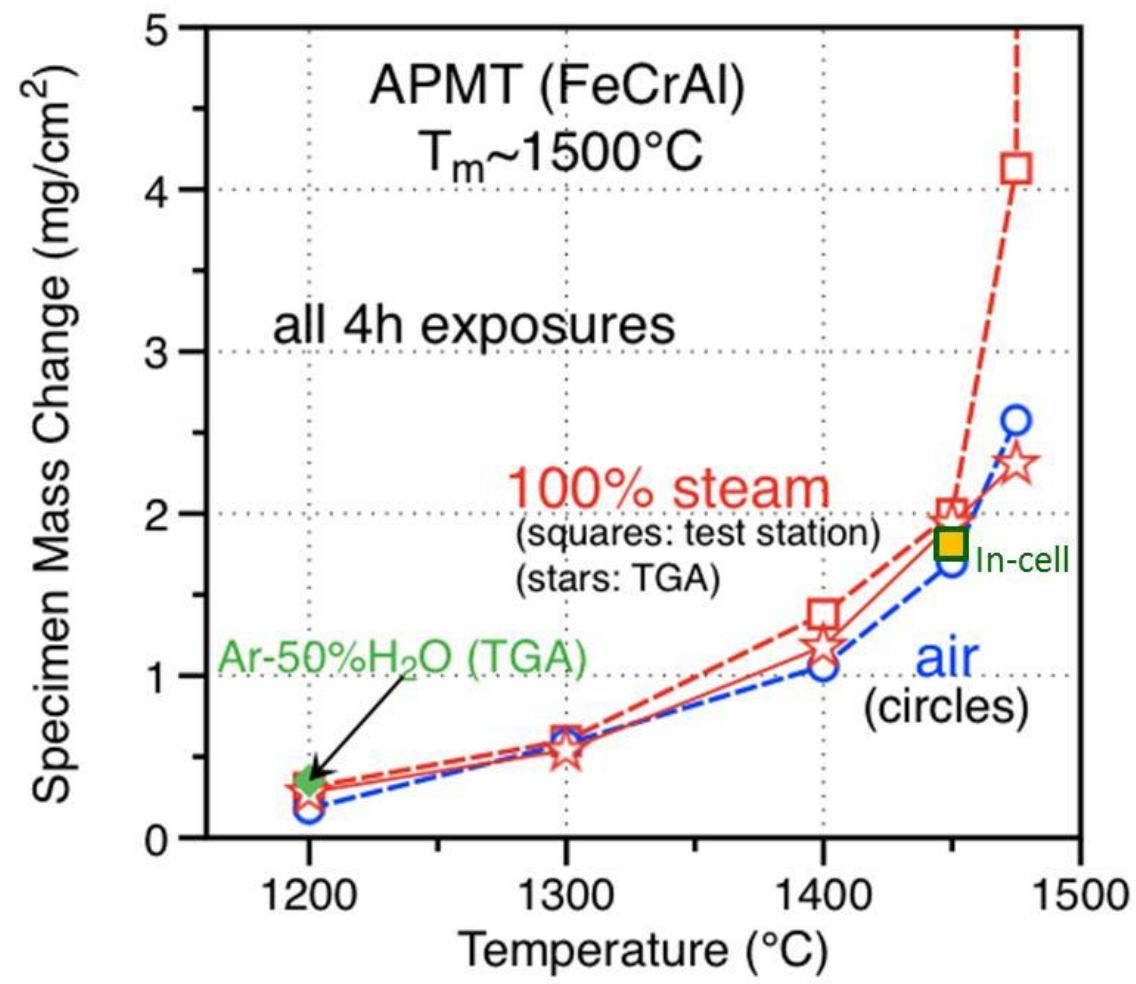

Figure 33 Specimen mass change of FeCrAl alloy APMT specimen exposed in the in-cell module at $1450{ }^{\circ} \mathrm{C}$ for $4 \mathrm{~h}$ (shaded symbol) compared to data compiled for out-of-cell module (open symbols). 


\subsubsection{DBA (or LOCA) module}

The in-cell DBA module is nearly identical to the out-of cell module described previously. The two systems are completely independent and all systems have been duplicated in the in-cell module. However, some modifications to the in-cell module were required for remote operation with manipulators in the hot cell.

\subsubsection{Manipulator control of DBA module}

Certain changes have been made in the design and assembly of the LOCA furnace component of the incell module in order to make it more amenable to manipulator operation in the hot cell. Specifically, quick connectors (Figure 26) were added for easy installation of the module, connecting out of cell piping with the in-cell module. The in-cell connections were positioned so that a vertical motion would be required to connect or disconnect the furnaces while the power lines for the out-of-cell module use standard hard-wire connections.

In addition, an X-Y moving table was added to the LOCA furnace base, so that the quartz tube and LOCA sample can be moved in X-Y directions for centering the LOCA sample. Figure 34 shows the difference in the furnace base for the out-of-cell and in-cell modules.

In order to reduce the difficulty of exchanging the quartz tube and LOCA samples from the LOCA furnace of the in-cell module, the bracket holding the furnaces to the furnace outer frame on the in-cell module was modified so that loosening the bracket can be operated with manipulators remotely. The differences in the furnace bracket for the out-of-cell and in-cell modules are shown in Figure 35.

An electronic valve of the quench tank (adding water) in the out-of cell module was replaced with a mechanical valve for the in-cell module in order to increase the reliability. Some electronic valves were upgraded for the same reason. Figure 36 shows the differences in the quench tank valves for the out-ofcell and in-cell modules.

Figure 37 shows the panel installed on the in-cell module to facilitate making the connections of thermocouples with manipulators. The out-of-cell module does not utilize this panel arrangement. 

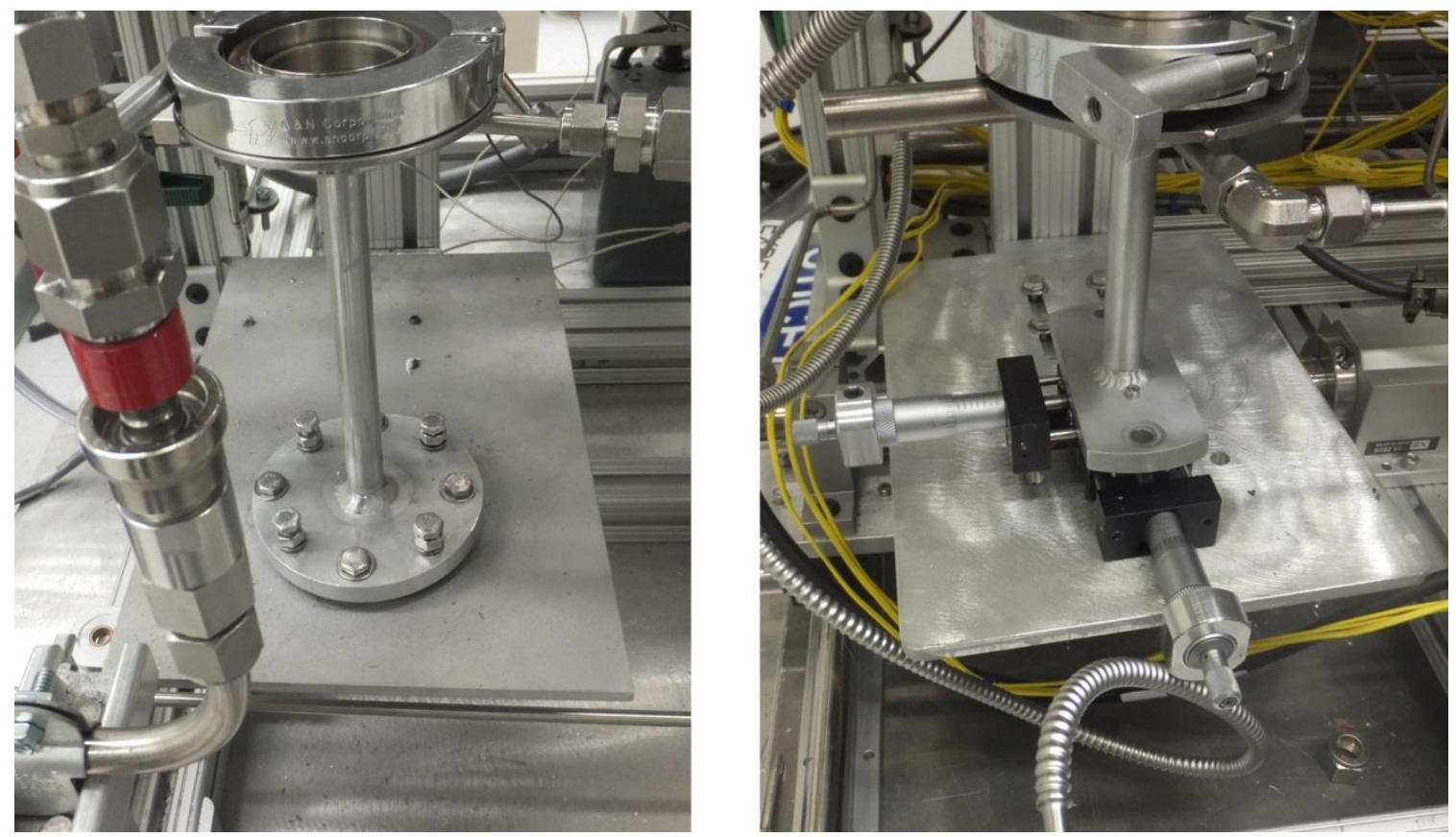

Figure 34 Furnace bases of the out-of-cell (left) and in-cell (right) attachments for the LOCA furnaces.
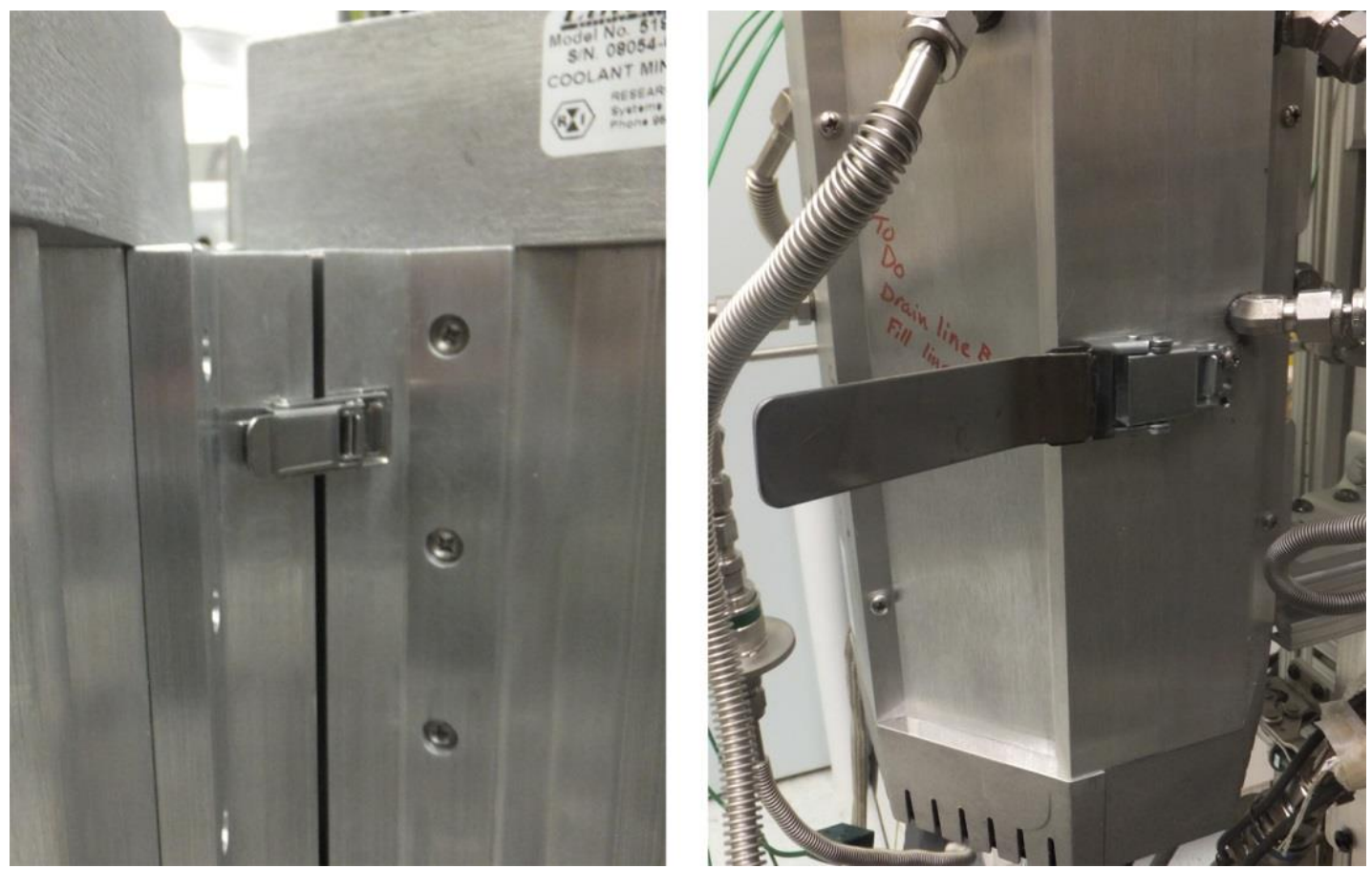

Figure 35 Furnace brackets of the out-of-cell (left) and in-cell (right) attachments for the LOCA furnaces. 

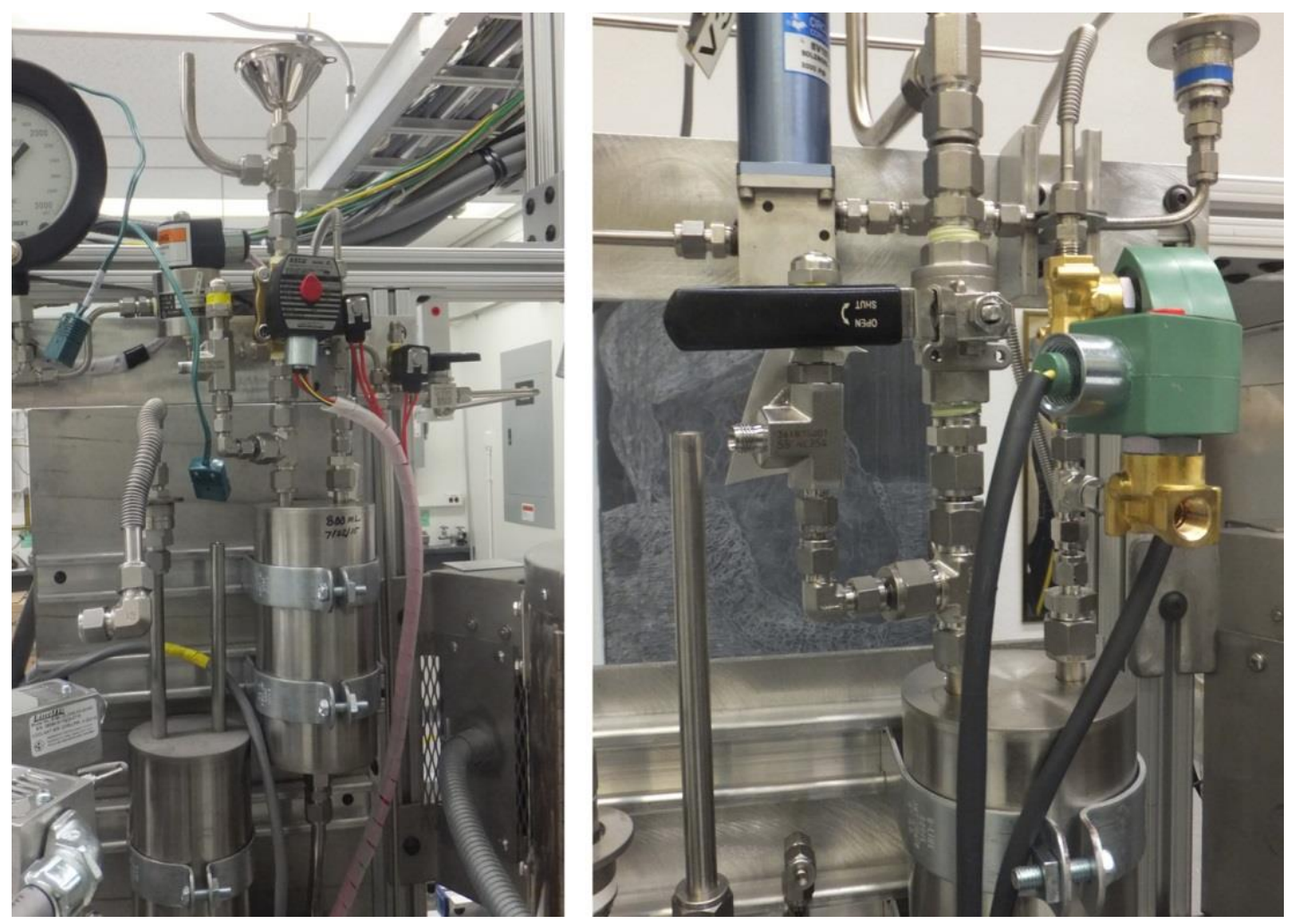

Figure 36 Quench tank valves of the out-of-cell (left) and in-cell (right) attachments for the LOCA furnaces.

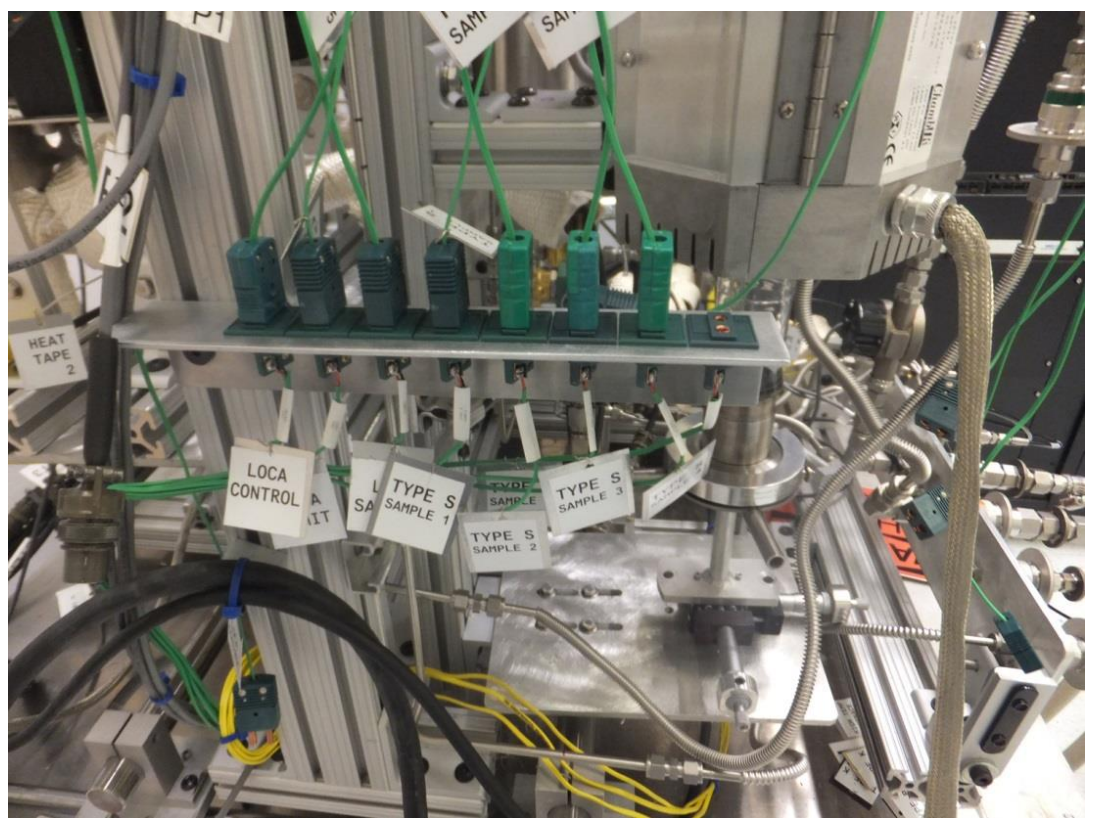

Figure 37 Thermocouple panel of the in-cell LOCA system. 


\subsubsection{Safety analysis}

An operating guideline was written for the operation of the SATS [11]. This guideline was reviewed and approved by the facility manager, safety officer, radiation control officer and the quality control manager. This guideline was used as input to the Un-reviewed Safety Question Determination (USQD). The outcome of the evaluation of the new activity did not require the SAR to be updated as the SATS facility's operation falls within its safety requirements.

\subsubsection{In-cell and out-of cell comparison}

LOCA integral tests have been successfully performed with the in-cell module. Specifically, LOCA testing with $\mathrm{Zr}$ alloy tubing was conducted up to $1200^{\circ} \mathrm{C}$ in both modules. The temperature profiles of the control thermocouple are in excellent agreement between the out-of cell module (Figure 38) and the incell module (Figure 39).

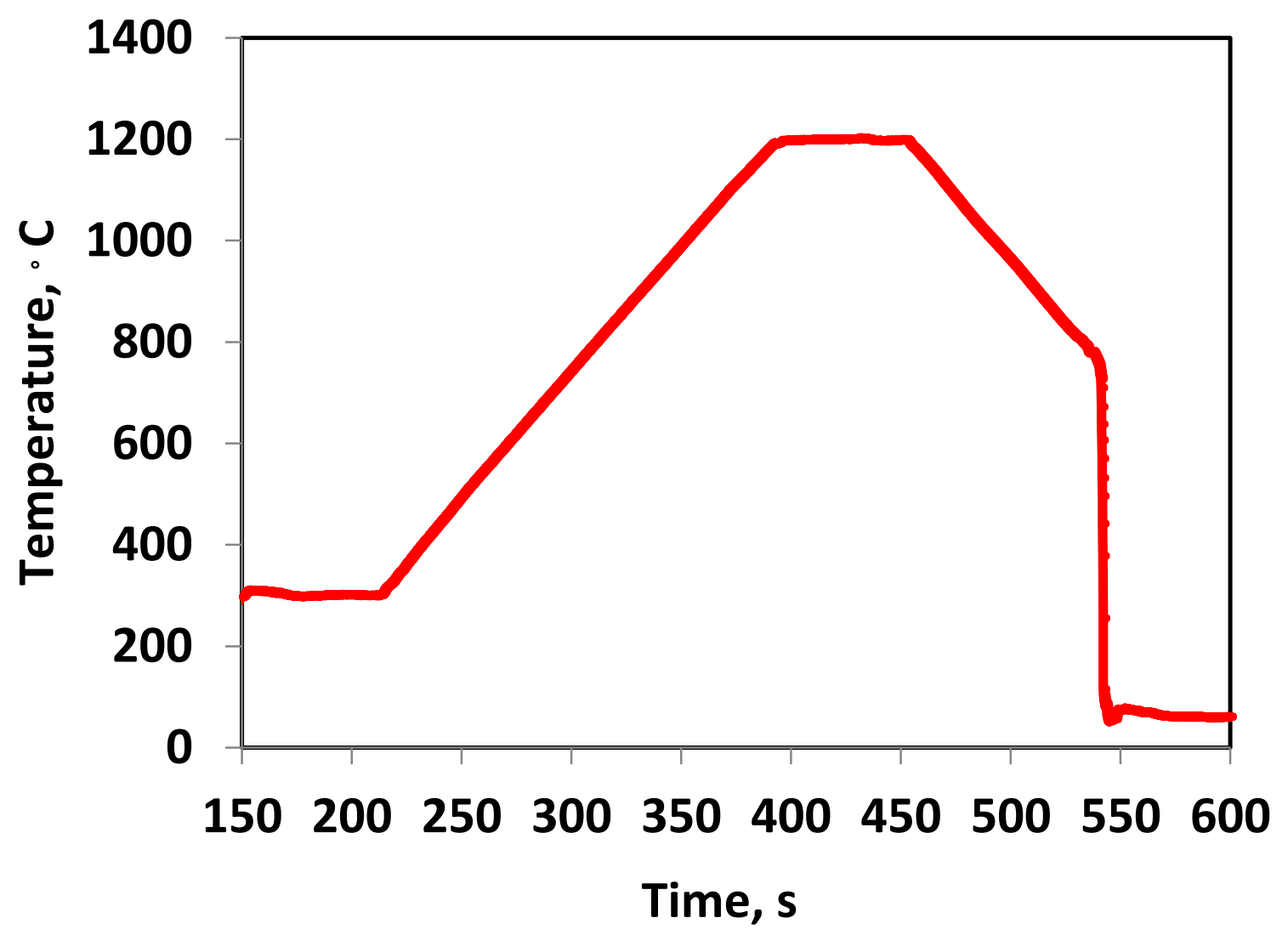

Figure 38 Temperature profile of the control thermocouple for a LOCA test performed with the out-of cell LOCA module. The sample was controlled heated to $1200^{\circ} \mathrm{C}$ at $5^{\circ} \mathrm{C} / \mathrm{s}$, held at $1200^{\circ} \mathrm{C}$ for $60 \mathrm{~s}$, cooled to $800^{\circ} \mathrm{C}$ and then water quenched. 


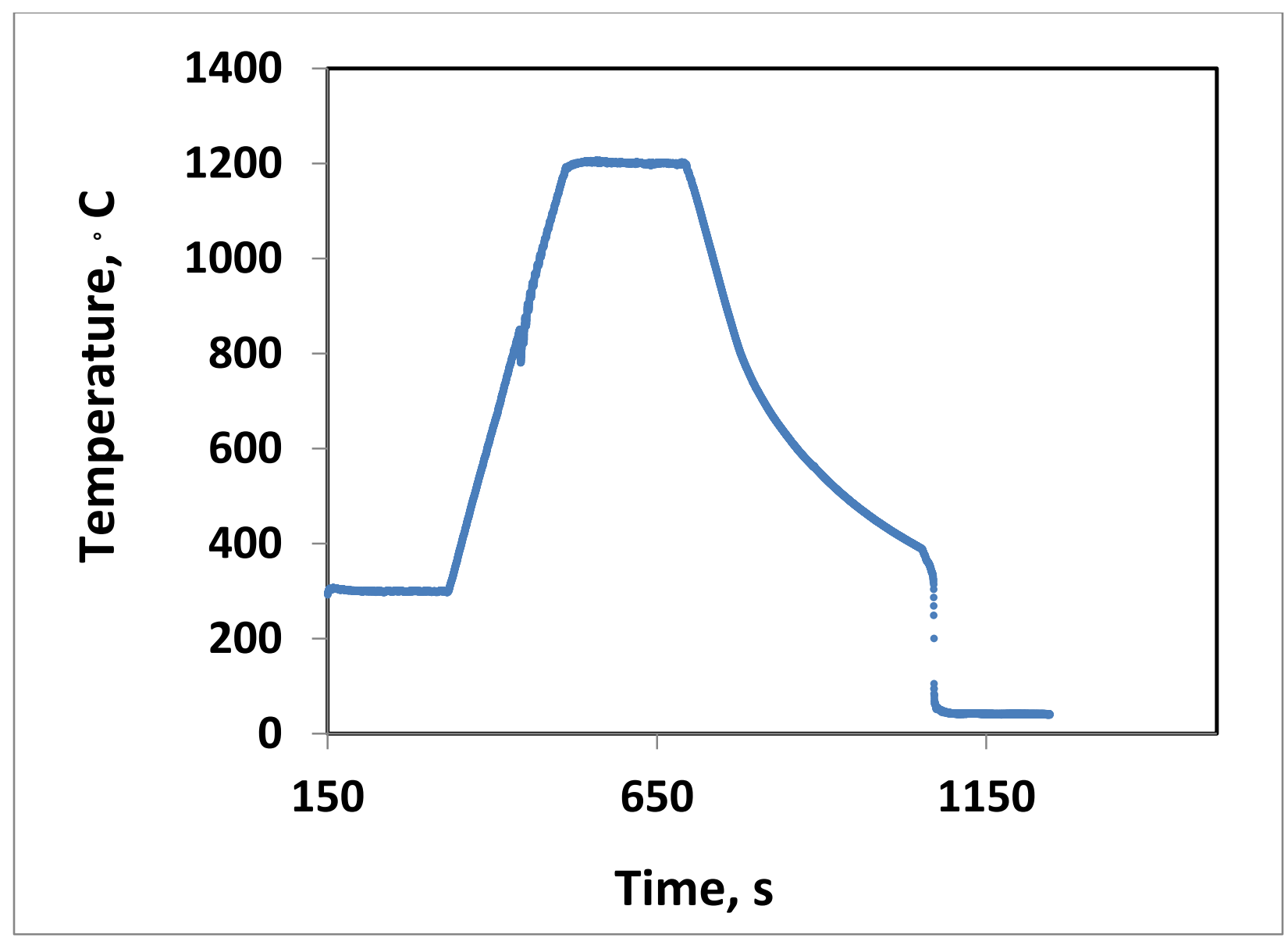

Figure 39 Temperature profile of the control thermocouple for LOCA test performed with the in- cell LOCA module. The sample was controlled heated to $1200^{\circ} \mathrm{C}$ at $5^{\circ} \mathrm{C} / \mathrm{s}$, held at $1200^{\circ} \mathrm{C}$ for $180 \mathrm{~s}$, cooled to $400^{\circ} \mathrm{C}$ and then water quenched.

\subsubsection{Support infrastructure required for LOCA tests in hot cell}

The following devices and equipment will be required for LOCA test sample preparation, completion, and post-test examinations:

- Fuel removal device

- Corrosion layer removal device

- Test train assembly device

- Thermocouple attachment/welder

- Cladding end-cap welding system

- Four-point bending equipment

- Hydrogen determination capability (Example: LECO hydrogen Determinator)

- Oxygen determination capability (Example: LECO oxygen Determinator) 


\section{REFERENCES}

[1] M. Billone, Y. Yan, T. Burtseva, R. Daum, "Cladding Embrittlement During Postulated Loss-of-Coolant Accidents," NUREG/CR-6967, (2008).

[2] P. Hofmann, Journal of Nuclear Materials, 270, (1999) 194.

[3] M. Steinbrück, et al., Nuclear Engineering and Design, 240, (2010) 1714.

[4] Y. Yan, R. V. Strain, T. S. Bray, and M. C. Billone, "High Temperature Oxidation of Irradiated Limerick BWR Cladding," NUREG/CP-0176, May 2002, pp. 353-372.

[5] Y. Yan, R. V. Strain, and M. C. Billone, "LOCA Research Results for High-Burnup BWR Fuel," NUREG/CP0180, Mar. 2003, pp. 127-155.

[6] Y. Yan, T. Burtseva, and M. C. Billone, "LOCA Results for Advanced-Alloy and High-Burnup Zircaloy Cladding," NUREG/CP-0185, June 2004, pp. 97-121.

[7] Y. Yan, M. C. Billone, T. A. Burtseva, and H. M. Chung, "LOCA Integral Test Results for High-Burnup BWR Fuel," NUREG/CP-0192, Oct. 2005, pp. 138-158.

[8] M. Moalem, D.R. Olander, Oxidation of Zircaloy by steam, Journal of Nuclear Materials, 182 (1991) 170.

[9] D.R. Olander, "Materials chemistry and transport modeling for severe accident analyses in light-water reactors I: External cladding oxidation," Nuclear Engineering and Design, 148 (1994) 253-271

[10] Y. Udagawa, F. Nagase and T, Fuketa, "Effect of Cooling History on Cladding Ductility under LOCA Conditions", Journal of Nuclear Science and Technology, 43:8, (2006) 844-850

[11] Y. Yan and J. Keiser, "Procedure for In-cell Severe Accident Test Station Tests", AFC-SATS Test-001, rev 0 [12] Bill of Material Components for the in-cell SATS, August 2015.

[13] B. A. Pint, K. A. Terrani M. P. Brady, T. Cheng and J. R. Keiser, "High Temperature Oxidation of Fuel Cladding Candidate Materials in Steam-Hydrogen Environments," Journal of Nuclear Materials, 440 (2013) 420 . 

ORNL/TM-2015/556

\section{INTERNAL DISTRIBUTION}

1. M. Snead

2. M. Howell

3. J. Keiser

4. Y. Yan

5. K. Terrani
6. B. Pint

7. J. Miller

8. M. Farrar

9. ORNL Office of Technical Information and Classification

\section{EXTERNAL DISTRIBUTION}

10. F. Goldner (DOE)

11. J. Carmack (INL) 


\section{OAK RIDGE NATIONAL LABORATORY}

